\title{
AVALIAÇÃO DA RESISTÊNCIA AO CISALHAMENTO DE TRÊS SISTEMAS DE NÚCLEOS INTRA-RADICULARES
}

Dissertação apresentada à Faculdade de Odontologia de Bauru, da Universidade de São Paulo, como parte dos requisitos para obtenção do título de Mestre em Odontologia (Área de Reabilitação Oral). 


\section{AVALIAÇÃO DA RESISTÊNCIA AO CISALHAMENTO DE TRÊS SISTEMAS DE NÚCLEOS INTRA-RADICULARES}

ANUAR ANTÔNIO XIBLE

Dissertação apresentada à Faculdade de Odontologia de Bauru, da Universidade de São Paulo, como parte dos requisitos para obtenção do título de Mestre em Odontologia (Área de Reabilitação Oral).

(Edição Revista)

Orientador: Prof. Dr. Accácio Lins do Valle

Bauru

2000 
Xible, Anuar Antônio
Xa Avaliação da resistência ao cisalhamento de três sistemas de núcleos intra-radiculares. / Anuar Antônio Xible. - Bauru, 2000.

92p. : il. ; $29,7 \mathrm{~cm}$.

Dissertação. ( Mestrado ) - Faculdade de Odontologia de Bauru. USP.

Orientador: Prof. Dr. Accácio Lins do Valle

Autorizo, exclusivamente para fins acadêmicos e científicos, a reprodução total ou parcial desta dissertação, por processos fotocopiadores e/ou meios eletrônicos.

Assinatura do autor:

Data: $04 / 05 / 2000$ 
28de junho de 1967

Santa Tereza - ES

Filiação

$1984-1988$

Associações
Nascimento

Luiz Xible

Zelinda Melotti Xible

Curso de Graduação em Odontologia na Faculdade de Odontologia da Universidade Federal do Espírito Santo.

ABO-ES - Associação

Brasileira de Odontologia do ES.

APG - Associação dos PósGraduandos da Faculdade de Odontologia de Bauru. Universidade de São Paulo. 
“E orio corresozinho... Vai seguindb oseu caminho.

Nãopredisa ser empurradb. Pára umpauquinhonoremansa. Apressa-senas

cadhoeiras.

Sabequehá um ponto dedhegada esen caminhoéseguir emfrente

É vitorioso, abraçandbautros rios.

O mar éa sua realizaçãa

É ter feitoa caminhada.

A vida écamoumrio.

Por queapressar?

Por queempurrar a vida?

Por quedhegar antes desepartir?

Toda natureza não tempressa. Vai seguindbo seu caminha.

Assiméa árvore, assimsão os animais. Tudb queéapressadb perdeo gosto e o sentidb. Tudbtemseu tempo.

Não imparta ter nascidba mil au a umquilômetrodomar.

Importanteéchegar aomar.

Importanteédzer quedhegue!! E porquedhegue, sinto-meræalizadb"

'Senãohaner frutos valeuabdezadesficres

Senz̃ohaver flores valeuasombradłsfolhes

Senãohaver folhes valeu a intençãodasemente".

(Henil ) 


\section{Dedcoestetrabalha}

Aos mas peis Luiz eZdincha responsáveis pda minha existêndia, que com muita dedcação, exemplo eluta ensinaramme prinápios morais devivênda dgnas de um ser humana. Nãoseria possíve ser o quesau eestar ondeestau semo carinho eapaio quesemprepermerama nossa convivêndia;

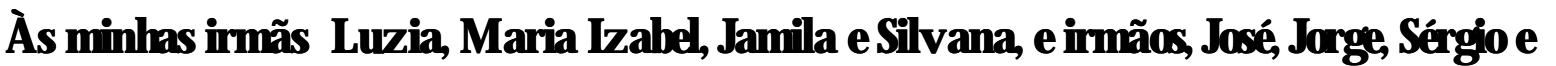

Luzz, que enbora dstantes, faziamse presentes nos momentos em que preisei, apoiandb eincentivandb mea continuar omeu caminho,

À Cristina, pdo amor e aumplicidade que sempre dedcau ao nosso relacionamento, instigandb-mesemprea seguir adante

“A perseverança ésuperiơ à vidêndia emuitas caisas quenão pockm ser superacas de imedato cedem quandb enfrentadbs parco a parca. A assidicade e a persittêndia são irresittívés e com o tempo superam e destrom as mais poderosas forças, pais o tempo éamigp eprotedor caqueles queusamojuízo para aguarcar a mahor ccasiãoe éinimigodestruidor daquelesqueseadantamsempensar." 


\section{Agradaimentos}

AoProf. Dr. AccádioLinscbValle meu arientador, pelos conhedimentos transmitidbs epdas orientaçães quesemprecontribuíram para o meu crescimento profissional , pda honesticade e comprometimento com o qual acompanhou o desenvivimento deste trabalho;

Em eqpeial, aos Profs Dr. Lús Femencb Pegarara Dr. Gérson Borfante e Dr. Accádio Lins db Valle pela oportunicade da rẹlização deste aurso e assim poder tornar-me mestre e um profissional mais preparadb à partir dos conhedimentos adquiridos no decorrer destes anos,

Ao Profs Dr. Paulo Amarante de Araúja Dr. Joé Mandali, Dr. Carlos dbs Rès Araúja pelo apoio, amizade e honestidade, val ores importantíssimos para dhegar onde chegue;

A JozéRdartoPereira Lauris pda anál iseetatística;

“Pareceme não ser justo rogar ao juiz e fazer-me absdver por mèo de súplicas. É precisoesdarecêloeconvencêlo". 
Acs mas colegescleturma pda amizadequehgenos une, pelos momentos vividbs e dviddbs e por toob o respeito, confiança e sincericade André, Carlos, Danida, Juliano, Leí́áa, Mário, Murilo, Néson, Sérgo, Vinídus P., Vinídus J., Vagner e William

Emepeial agacker aosamigos Vagner. Murilo, Henrique, Leíáa, Mário, Vinídus Porto pda presença constantenos momentos bons eruins,

Aoamigp Mário Bittencart, que no início da minha carreira pudłmos conviver e trocar experiênaias funcamentais para tơnar-me mais capadiadb e eficienteno que meproponhoa realizar;

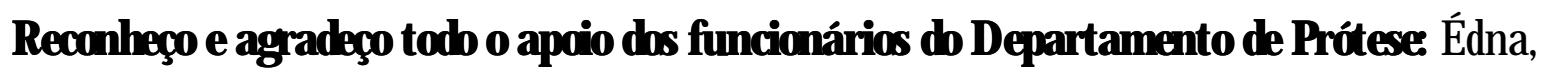
Ângda, Révanilda, Luzia, Geraldb, Did, Lílian, Débora eMarcda,

Acsfuncianáriosch PóśGradregãa D. Ana, Cleusa, Débora, Giane NeideAurêlioe Hedása pelos mamentosqueconvivemos,

Ao Carlos funcionário db almoxarifadb pła atenção dspensada na exeaçãa desse trabalho; 
À CAFES pda concessão da bdsa deetudbs, tornandb possíved a realização db Curso deMestradb;

Acspedentes pda confiança erespeito ao meu trabal ho,

Ao Hehbet Saza Mendes pelo apdioeconfiança depoositadbs nestetrabal ho;

E a tads as pesces que dreta au indretamente contribuíram pera que o man djeivopropotofomeatingich a rølizaçãocbarsoectstetrabilho

“A perseverança éessendal a toobs. “ Sórates. 


\section{SUMÁRIO}

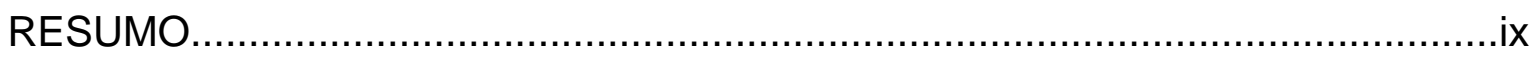

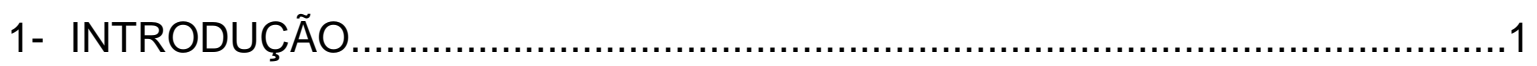

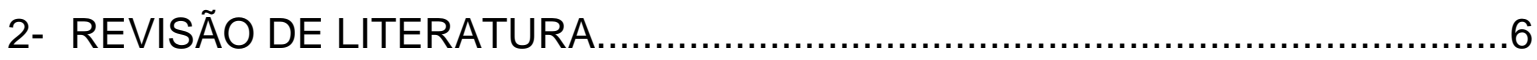

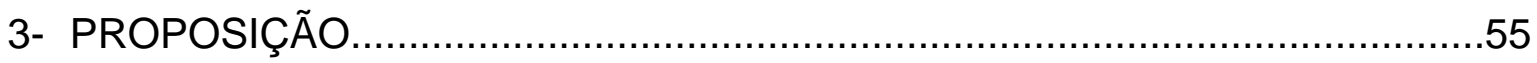

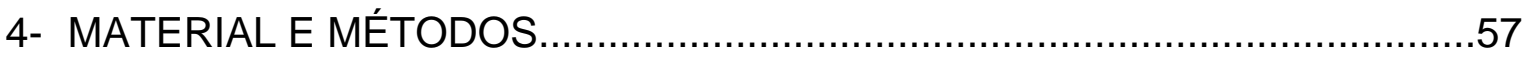

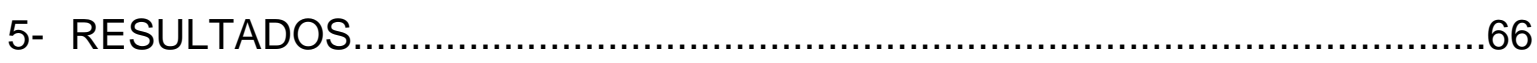

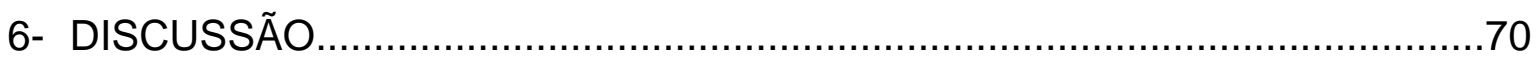

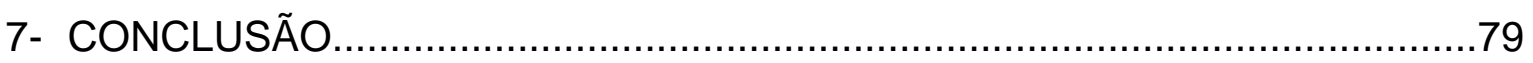

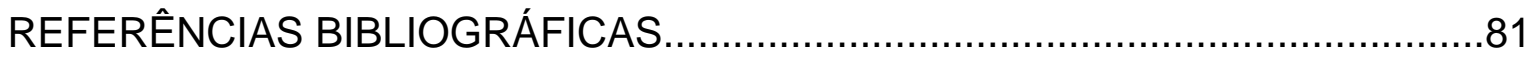

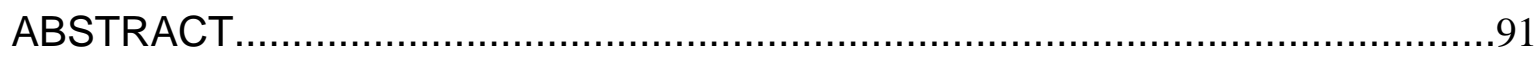




\section{LISTA DE FIGURAS}

\section{Material e Métodos}

Figura 4.1 - Pinos de cerâmica à base de dióxido de zircônio e de titânio

Figura 4.2 - Matrizes primária e secundária acopladas, para a confecção dos

corpos de prova 59

Figura 4.3 - Procedimento de ceroplastia .60

Figura 4.4 - Pino de cerâmica após a ceroplastia 61

Figura 4.5 - Espécimes após a desinclusão. 62

Figura 4.6 - Pino cerâmico posicionado para a inserção da resina composta.... 63

Figura 4.7 - Inserção da resina composta 64

Figura 4.8 - Espécimes prontos para o ensaio. .64

Figura 4.9 - Ensaio dos espécimes do grupo 1 65

\section{Resultados}

Figura 5.1 - Gráfico ilustrativo dos valores de carga suportados até a fratura para os três grupos estudados, expressos em MPa 69 


\section{LISTA DE TABELAS}

\section{Resultados}

Tabela 5.1 - Valores obtidos para os testes de resistência ao cisalhamento com os corpos de prova dos três diferentes grupos testados ( $\mathrm{MPa}$ )... .67

Tabela 5.2 - Médias dos valores de resistência ao cisalhamento dos 3 grupos testados ( MPa ) .68

Tabela 5.3 - Dados do teste estatístico de análise de variância a um critério obtidos dos ensaios de cisalhamento. 68

Tabela 5.4-Teste de Tukey para comparações múltiplas entre os grupos testados. 69 


\section{RESUMO}

Foram comparadas as resistências adesivas ao cisalhamento presente entres os componentes de três diferentes sistemas de núcleos intra-radiculares. Foram utilizados pinos de cerâmica à base de dióxido de zircônia ( Cosmopost ), e pinos de titânio ( Tenax ). Os preenchimentos testados foram a resina composta fotopolimerizável ( Tetric Ceram ) e porcelana vítrea fundível ( IPS Empress Post ).

Foram confeccionados 30 espécimes divididos em 03 grupos: 10 espécimes de pinos de cerâmica à base de zircônia, aos quais foi fundida porcelana vítrea; 10 espécimes de pinos de cerâmica à base de zircônia e resina composta fotopolimerizável; e 10 espécimes de pinos de titânio e resina composta fotopolimerizável, todos, de acordo com o fabricante. Os espécimes do grupo 1 necessitaram ser ajustados, por desgaste, à base de prova.

Todos foram submetidos a uma força de cisalhamento em uma máquina de ensaios universal Kratos, até fratura.

A análise estatística, assim como observações macroscópicas permitiu-nos concluir que:

1- A resistência encontrada entre os componentes dos corpos de prova do grupo Pino de Zircônia X Cerâmica IPS Empress Post apresentou resultados estatisticamente não significantes em relação ao grupo em que foi usado Pinos de Titânio X Resina composta.

2- Os resultados dos sistemas do grupo 1 - Pino de Zircônia X Cerâmica IPS Empress Post - e 3 - Pinos de Titânio X Resina Composta demonstraram diferença estatisticamente significante em relação ao grupo 2 , em que foi empregado o sistema dos Pinos de Zircônia X Resina Composta. 
INTRODUÇÃO 


\section{INTRODUÇÃo}

A Odontologia tem por princípio buscar a manutenção e o restabelecimento da saúde bucal, sendo que a prevenção ocupa um lugar de destaque, buscando preservar as condições naturais de saúde do ambiente bucal, prevenindo-o de qualquer patologia. No entanto, quando alterações encontram-se presentes, deve-se procurar restabelecer as condições de normalidade, tornando-se necessário o diagnóstico correto e a inter-relação entre as diversas áreas da Odontologia para o sucesso de um tratamento.

A odontologia restauradora objetiva restabelecer a forma, a função e a estética desse sistema. Para tanto, é de fundamental importância o conhecimento a respeito de alguns problemas tais como a doença cárie e sua correlação com as estruturas adjacentes, o domínio de técnicas restauradoras, o conhecimento sobre os inúmeros materiais disponíveis, suas características, propriedades e comportamento clínico para que sua indicação seja correta e precisa.

A introdução das coroas de porcelana pura se iniciou com Land $^{35}$, que utilizou uma folha de platina como subestrutura, submetida a um aquecimento em alta temperatura controlada em um forno a gás, em 1886, produzindo as primeiras "inlays" e coroas de porcelana felsdpática fundidas. Os sistemas de porcelanas puras, a despeito de suas vantagens estéticas, não conseguiram popularidade, até a introdução das porcelanas dentais com infraestrutura reforçada de alumina. Seu uso foi ofuscado por notável desenvolvimento dos sistemas metalo-cerâmicos que ocorreu com a adição de leucita às fórmulas das porcelanas, elevando o coeficiente de expansão térmica, e permitindo sua fusão a ligas metálicas na construção de coroas unitárias e próteses parciais fixas. Um refinamento nas técnicas de metalo-cerâmicas dominou as pesquisas em cerâmicas dentais nos últimos 35 anos, resultando em ligas melhoradas e ótima adesão entre metal e a porcelana. A criação do sistema de coroas totais de porcelana CEREC (Cerestore, Coors Biomedical) e um sistema de coroas de vidrocerâmicos puros DICOR ( Dentsply/York Division ) nos anos 80 permitiu avanços na área de processamento de cerâmicas e estimulou um renovado interesse em próteses totalmente cerâmicas ${ }^{35,52}$ 
O número de sistemas de porcelanas puras cresceu de maneira significativa na última década, sendo disponíveis no mercado, em 1996, pelo menos seis deles no mercado: as coroas de porcelana puras fundidas sobre refratários ( ex: Duceram/Degussa-Hüls, Fortune/Williams ), a técnica da porcelanas fundidas ( ex: Empress Ivoclar; OPC/ Jeneric Pentron), os sistemas de fases interpenetrantes de alumina e vidro ( ex: In-Ceram, Hi-Ceram/Vita ), os sistemas de maquinação de porcelanas ( ex: Celey/Mikrona e CEREC/Siemens ), vidro cerâmico fundido ( ex: Dicor/Dentsply ) e aqueles advindos de núcleos de alumina altamente sinterizados aliados ao processo de maquinação ( ex: Procera/Nobel Biocare ). ${ }^{35}$

Esses sistemas de coroas totalmente cerâmicos são uma opção para pacientes com alergias a metal, além de seu melhor desempenho estético. Uma estética extraordinária, translucidez e vitalidade podem ser atingidas com esses materiais. ${ }^{53}$

Uma última fronteira permanece para se conseguir resultados extremamente estéticos: o uso de pinos intra-radiculares obtidos de ligas metálicas. Muitos esforços têm sido feitos para substituir esses materiais de pinos por outros também biocompatíveis, no entanto, estéticos. Os pinos metálicos produzem um efeito escuro, opaco, provocando uma sombra acinzentada em dentes restaurados, particularmente na região anterior. ${ }^{53}$

A colocação de núcleos intra-radiculares não reforça dentes tratados endodonticamente ${ }^{29}$,e sim substituem a estrutura coronária perdida, sendo que a função primária do pino intra-radicular é reter o núcleo de preenchimento, assim como transmitir forças oclusais da coroa para a superfície radicular. Assim, o corpo da estrutura dental remanescente é que provê resistência ao dente tratado endodonticamente.

Algumas técnicas preconizam como contornar o problema de raízes escuras em dentes tratados endodonticamente, usando a técnica de tunelamento, removendo-se a estrutura dental escura em direção apical, que permite a inserção de material opaco tipo ionômero de vidro para clarear a raiz. Essa abordagem, no entanto, enfraquece a estrutura dental, levando-a à fratura. ${ }^{52}$

Desde a introdução das resinas compostas na década de 60 , tem sido ampla sua utilização e sua indicação na confecção de núcleos de 
preenchimento quando restaurações estéticas se fazem necessárias. Dessa forma, o desenvolvimento dos estudos no sentido de se aprimorarem as propriedades destes materiais e a influência destas no seu comportamento clínico, ao longo dos anos, assumem papel de destaque e relevância entre os diversos trabalhos.

A grande maioria dos materiais restauradores disponíveis é incapaz de se aderir quimicamente às estruturas dentárias. Ao contrário, meios de retenção como uma ligação micromecânica ou uma íntima adaptação do material ao preparo cavitário ocorrem nesses casos. ${ }^{68}$

O grande problema do uso da resina composta como núcleo de preenchimento é a contração sofrida durante a polimerização e, como conseqüência, o rompimento das ligações da resina com o remanescente dentinário, aparecendo fendas na interface dente/restauração, que podem resultar em infiltração sob a coroa de porcelana. Outra desvantagem advém do relativamente baixo módulo de elasticidade das resinas compostas, que pode gerar um sistema de deformação plástica sob a coroa cimentada. Com repetidas cargas cíclicas relativas aos anos em função, o núcleo de preenchimento sofrerá flexão microscópica, o que gradualmente causará microfraturas e posterior desintegração do cimento e falha na restauração. Portanto, ao se optar por um sistema de reconstrução intra-radicular estético, deve-se considerar que este seja resistente o suficiente para substituir os sistemas de núcleos metálicos fundidos e oferecer as características estéticas da resina ou porcelana.

Para atingir esse objetivo, novos materiais cerâmicos foram desenvolvidos e, dentre eles, encontra-se um composto de cerâmica à base de dióxido de zircônia, que atua como pino intrarradicular, que se adere quimicamente à cerâmica vítrea que, por sua vez, atua como núcleo de preenchimento ${ }^{53}$ Esse pino intra-radicular pode ser usado também como base para suporte de núcleo de preenchimento de resina composta. ${ }^{45,55,68,70}$

Apesar de desejável, a resistência não é necessariamente a mais importante consideração sobre um material restaurador, devendo-se ter cuidado ao se interpretarem dados de resistência, considerando as propriedades mais apropriadas para cada aplicação dental individualmente. O grande desafio 
relativo aos materiais dentários está em se desenvolver uma melhor relação entre a micro-estrutura e propriedades, e seu comportamento clínico.

Os valores de resistência podem se tomados de várias maneiras. Para os materiais dentários friáveis, os testes mais usados são os de resistência à tração diametral e a resistência à compressão, pois são de fácil execução e razoavelmente reproduzíveis. $^{48}$

As considerações de resistência dos materiais são colocadas à prova quando se consideram as combinações entre esses materiais. Por exemplo, é importante confiar na resistência entre as ligas metálicas e porcelanas, para que sejam materiais de escolha em restaurações.

Com esse intuito, o presente trabalho se propõe a investigar a resistência ao cisalhamento de resina e porcelana quando usadas como reconstrução coronária de núcleos intra-radiculares. 
REVISÃO DE LITERATURA 


\section{REVISÃO DE LITERATURA}

Em 1954, HEALEY ${ }^{30}$ descreveu uma técnica para restauração de dentes anteriores traumatizados, com envolvimento pulpar acompanhado de perda extensiva de substância dentária. Nos casos em que a câmara pulpar fosse muito larga, o simples preenchimento não seria suficiente para suportar uma coroa de jaqueta confeccionada em resina. O autor mostrava a confecção de um núcleo metálico fundido, cujo tamanho intracanal deveria ser pelo menos o tamanho da coroa a ser colocada.

Em 1967, McLEAN ${ }^{43}$ descreveu uma técnica que demonstrava sua preocupação com a estética que as coroas de porcelana pura poderiam proporcionar, dependendo da opção que fosse feita para prover o núcleo intra-radicular e o preenchimento coronário. A parte coronária do núcleo metálico fundido deveria ser adaptada a um tubo de alumina, durante sua ceroplastia, que posteriormente seria cimentada sobre ele, permitindo a instalação de uma coroa totalmente cerâmica. Dessa maneira, seria possível aproveitar melhor as características estéticas das porcelanas.

BARABAN, em $1972^{6}$ preconizou o uso de resinas compostas ativadas quimicamente como material de preenchimento da parte coronária de dentes unirradiculados posteriores que receberam pinos pré-fabricados Parapost, de paredes paralelas, serrilhados, como retentor Intra-radicular, aliado ao uso de pinos dentinários. Destacou como vantagens do uso desse material: a economia de tempo; economia de material; imediata preparação do dente quando existe pouca estrutura dentária, pois provê estrutura necessária para o preparo de dente, o que facilita a confecção de coroa provisória; assegura uma boa adaptação do núcleo de preenchimento a dente contíguo; permite colocar pinos intraradiculares não paralelos aos pinos dentinários, aumentando a retenção do núcleo de preenchimento. Nesse mesmo trabalho, o autor questiona se existe suficiente retenção entre o pino intra-radicular e o núcleo de preenchimento de resina, não somente durante os procedimentos subseqüentes, mas também durante a função. 
Caso isso fosse verdade, o autor visualizava que os núcleos metálicos fundidos não seriam mais necessários.

Em 1975, GARVIE; HANNINK; PASCOE $^{27}$ relataram que uma cerâmica poderia ser modificada por um mecanismo poderoso, que permitiria uma dispersão de dióxido de zircônio ( Zircônia ) tetragonal metastásica tornando-se zircônia cúbica.

Acredita-se que a transformação da fase tetragonal da zircônia em monoclínica seja uma transformação martensítica, rápida e sem difusão. Aventou-se que essa fase tetragonal da zircônia não tem condições de permanecer estável, quando submetida a um processo de resfriamento até a temperatura ambiente e sob pressão atmosférica.

Os autores explicam que o dióxido de zircônio possui três formas alotrópicas ( alotropia é o poder que um elemento químico tem em se cristalizar em mais de um sistema cristalino e ter, por isso , diferentes propriedades físicas ):monoclínico, tetragonal e cúbico. A transição entre os dois primeiros envolve um grande volume de expansão, que proporciona as propriedades refratárias do dióxido de zircônio puro, por essa razão usado em estruturas de cerâmicas. Este processo de transformações mais extensas pode ser suprimido por uma total estabilização na forma cúbica, mas é de conhecimento geral que as propriedades mecânicas mais úteis são obtidas num material multifásico, conhecido como zircônia parcialmente estabilizada. Foi demonstrado que um precipitado em escala fina de zircônia monoclínica, em uma matriz cúbica estabilizada, aumenta a resistência da zircônia parcialmente estabilizada.

A zircônia tetragonal metastásica existe em temperatura ambiente, somente em partículas menores que 30nm de diâmetro; nesse caso, a estabilidade é devida à baixa energia de superfície da fase tetragonal, comparada com a fase monoclínica.

Em folhas de zircônia levadas a uma espessura delgada, não através de processo mecânico, mas obtidas por processos de emissão de feixes de íons, foram preparados padrões por difração de Raios-X onde se identificam claramente a mistura de fases cúbicas e tetragonais. Ao microscópio eletrônico de 
transmissão, essas amostras revelam uma estrutura dupla, cujas partículas de segunda fase com mais de 100nm de diâmetro são, sem dúvida, tetragonais. Amostras cuidadosamente preparadas não demonstraram nenhuma evidência de fase monoclínica, a não ser quando o diâmetro das partículas de segunda fase era maior que 100nm. Essa conclusão é suportada pela continuidade no aquecimento em $1500^{\circ} \mathrm{C}$; uma repentina mudança no tamanho é normalmente um indicador sensitivo da presença de zircônia monoclínica.

A fase tetragonal é metastásica e pode ser transformada prontamente em monoclínica, por exemplo, por desgaste com diamante na superfície ou por pulverização durante o preparo para obtenção de fotografias com Raios-X. A estabilização da fase tetragonal vem de uma combinação do efeito da energia de superfície, e uma contração da matriz rígida, a qual se opõe à transformação para uma forma monoclínica menos densa. Como resultado, a transformação pode ocorrer localmente, se a manutenção do controle estrutural da superfície for removida. Isso é, provavelmente, acionado por tensão de cisalhamento. Essa é a transformação que tem sido observada nas folhas finas durante a exposição de feixes elétricos em um microscópio eletrônico.

A presença da fase tetragonal, que pode se reverter para a fase monoclínica, tem um número importante de conseqüências, como um significativo aumento na resistência. A média de resistência à ruptura transversa é de 650MPa em cerâmica de zircônia deformada no teste de dobramento de quatro pontos. Essa resistência é comparada com os valores mais altos de óxidos de cerâmica - em alumina em pó fino. Em contraste, a resistência de uma zircônia parcialmente estabilizada contendo uma fase puramente monoclínica é de 250MPa. O aumento na resistência é conseguido por um aumento no trabalho de fratura acima de 500 $\mathrm{Jm}^{-2}$, ao invés de uma redução do tamanho do defeito, como geralmente é obtido pela redução do tamanho do grão ou porosidade, como em muitas outras cerâmicas. Parte do aumento do trabalho de fratura provavelmente aparece de uma fase dispersa interagindo com o local da trinca. A contribuição mais importante vem da absorção de energia durante a transformação martensítica de células tetragonais para monoclínicas. 
Uma posterior contribuição para o aumento de resistência advém do acabamento de superfície. Em contraste com outros materiais friáveis, o desgaste na superfície aumenta a resistência ao invés de diminuí-la, como acontece com uma superfície polida. Essa diferença é associada a um aumento no conteúdo monoclínico criado na superfície durante o desgaste. Uma superfície, no estado em que permanece quando é feita a queima, não tem fase monoclínica, mas é gerada por transformação advinda da fase tetragonal - durante o desgaste, processo esse que induz a tensões de compressão na superfície e aumenta a possibilidade à ruptura transversa. O polimento cuidadoso remove alguns dos materiais monoclínicos, sem transformar nenhum em tetragonal e, assim, reduz a tensão na superfície às forças para fratura. Uma redução similar de resistência pode ser atingida por tratamento térmico, que remove a tensão sem reduzir o conteúdo superficial da fase monoclínica. O aumento no conteúdo monoclínico na superfície é combinado com diminuição no conteúdo tetragonal.

Pode ser notado que um sistema de ligas baseado em zircônia tem muitas propriedades em comum com sistemas baseados em ferro, incluindo três alótropos, transformação martensítica e fases metastásicas. A vasta quantidade de materiais com diferentes propriedades formada no sistema do ferro levou os autores a acreditarem que a zircônia estabilizada parcialmente pudesse ser considerada análoga ao aço.

Em 1979, GUZY; NICHOLLS ${ }^{29}$ compararam in vitro a resistência de dentes tratados endodonticamente com e sem pino intra-radicular cimentados, com o propósito de determinar se os pinos intra-radiculares reforçariam realmente os dentes tratados endodonticamente. Foram utilizados 59 dentes incisivos centrais e caninos, os quais tiveram seus condutos radiculares preenchidos com guta-percha, pela técnica da condensação lateral. Em 29 dentes, não foram utilizados pinos intra-radiculares, e posteriormente foi removido $1 \mathrm{~mm}$ de material obturador aquém de suas junções cemento-esmalte. Nessa região foi feita, então, restauração de silicato. Os outros 30 dentes receberam pinos intra-radiculares, tendo sido removido de 7 a $8 \mathrm{~mm}$ de material restaurador intracanal; pinos intrarradiculares Kerr Endo-post foram cimentados com cimento de Fosfato de Zinco nesses dentes e 
uma broca foi usada para preparar uma cavidade lingual, a qual recebeu uma restauração de silicato. Uma carga foi incidida num ângulo de $130^{\circ}$ em relação ao longo eixo dos dentes, a uma velocidade de $5 \mathrm{~cm}$ por minuto até fratura dos dentes. O resultado foi que não houve diferença estatística significante entre a média de carga aplicada para os dois grupos de dentes.

DEUTSCH et al. ${ }^{24}$ fizeram uma revisão de literatura em 1983, considerando todos os materiais para restaurações de dentes tratados endodonticamente disponíveis à época.

Os autores definem que os núcleos intra-radiculares podem se comportar de duas maneiras: primeiro quando existe estrutura coronária suficiente, os núcleos intra-radiculares reforçam a porção coronária tanto quanto a porção radicular do dente contra fratura. Segundo, quando não existe quantidade dentinária coronal suficiente , o núcleo intra-radicular é usado com a finalidade de repor essa estrutura dental perdida, para reter e suportar a restauração protética subseqüente.

Os autores classificam os pinos intra-radiculares quanto à retenção, sendo os mais retentivos os que possuem paredes paralelas, rosqueáveis (Tipo Kurer); em seguida, os pinos intra-radiculares de paredes paralelas, serrilhados; depois, seguem os pinos intra-radiculares de paredes paralelas, lisos e, por último, os de paredes paralelas, lisos com extremo cônico.

Também é discutida a corrosão, que presumivelmente acontece nos pinos intra-radiculares metálicos. Até aquele ano não havia relatos de associação entre corrosão e fratura radicular na literatura americana, ao contrário da literatura escandinava, que afirmava que a composição química dos materiais de confecção dos pinos intra-radiculares e suas interações levariam à corrosão. Os núcleos metálicos fundidos muitas vezes eram obtidos de ligas que continham estanho, antimônio, zinco, prata, cobre e níquel, além do ouro. O mecanismo da corrosão teria na corrente galvânica as condições necessárias para sua origem, pois os metais têm diferentes potenciais elétricos, sendo o estanho o principal responsável. Os produtos da corrosão se difundiriam através da dentina o que 
geraria posterior fratura dos dentes. Finalmente sugerem que não devem ser usados materiais diferentes na composição de núcleos intra-radiculares fundidos.

SORENSEN; MARTINOFF ${ }^{61}$ em 1984 fizeram um estudo clínico para investigar o significado de determinados fatores na confecção de núcleos intra-radiculares, que se relacionaram com suas sobrevidas. Dentre esses fatores estavam o desenho, comprimento, configuração da superfície e diâmetro. Compararam a taxa de sucesso clínico de métodos de reforço intra-coronário.

Os autores analisaram mais de 6000 pacientes de nove dentistas clínicos gerais. Os dentes foram examinados e comparados por meio de variáveis independentes de: ( $\mathrm{A}$ ) método de reforço intra-coronário, nas categorias de ( 1 ) núcleos metálicos fundidos, ( 2 ) Parapost e núcleo de preenchimento de Amálgama ou Resina Composta, ( 3 ) núcleos metálicos fundidos de Parapost, ( 4 ) pinos rosqueados, ( 5 ) Amalgamapin e ( 6 ) Pino dentinário com resina composta; ( B ) o tamanho do núcleo intra-radicular, que foi determinado radiograficamente, sendo que o tamanho registrado obedeceu a uma proporção de 1/4 mais o tamanho da coroa; e ( C ) modo de falha, que consistiu de dois grupos: os considerados restauráveis por falhas de deslocamento e os considerados não restauráveis por falhas originadas de fraturas horizontais e oblíquas, fratura vertical do dente e perfuração iatrogênica do dente. Os dentes com menos de um ano de tratamento não foram incluídos no estudo. Dentes tratados endodonticamente com história de falhas por problemas periodontais ou envolvimento com cáries também foram excluídos. Baseados nesses dados, 1273 dentes tratados endodonticamente foram selecionados dos 6000 pacientes registrados.

Desse total, 65,4\% não tinham reforço intra-radicular. A taxa de sucesso para esses dentes foi de $89,9 \%$. Dos dentes com reforço intra-coronário, os núcleos metálicos fundidos cônicos foram os mais encontrados ( $19,2 \%$ ) e obtiveram taxa de sucesso de $87,3 \%$. Os pinos Parapost que tiveram amálgama ou resina composta como núcleo de preenchimento foram usados em 10,4\% dos dentes e resultaram em uma taxa de sucesso de $97,7 \%$. Os outros grupos corresponderam a $5 \%$ dos dentes tratados endodonticamente. No entanto, observou-se que os 38 dentes que receberam Parapost e parte coronária fundidos 
tiveram $100 \%$ de sucesso. Do total de núcleos metálicos fundidos cônicos que falharam, aproximadamente $61 \%$ dos dentes poderiam ser restaurados novamente , enquanto que $39 \%$ dos dentes tiveram que ser extraídos.

BRYANT; MAHLER ${ }^{12}$ investigaram, em 1986, o módulo de elasticidade ( E ), das resinas compostas e do amálgama, medidos em GigaPascal ( GPa ). Treze marcas comerciais de resinas compostas híbridas e de macropartículas foram investigadas. Destas, 5 eram ativadas quimicamente, e 08 eram ativadas por luz halógena. Nestas últimas foram aplicados 200 segundos de luz para garantir perfeita polimerização. Foram usadas fitas matrizes de acetato para cobrir todos os espécimes durante a polimerização, os quais posteriormente foram testados em um ensaio de dobramento em três pontos. Os resultados foram apresentados dividindo as resinas híbridas e as de macropartículas em dois grupos, de acordo com seus módulos de elasticidade. As primeiras apresentaram um Módulo de Elasticidade ( $E$ ) entre 9,5 e 10,8GPa, sendo muito menos rígidas do que as de macropartículas que demonstraram um módulo de elasticidade entre 15,2 e $18,8 \mathrm{GPa}$. Os autores destacaram que os resultados não diferiram significativamente entre as resinas fotopolimerizáveis e autopolimerizáveis.

Também em 1986, OLIVA; LOWE ${ }^{49}$ estudaram a estabilidade dimensional das resinas compostas. As mudanças dimensionais, que são resultado de absorção de água, podem ser substanciais. Os autores concluíram que o equilíbrio entre sorção de água e expansão linear era conseguido ao final de seis dias. A expansão após seis dias não foi considerada significativa. A sorção de água e expansão linear se iniciam quando a resina composta é exposta à água, após polimerização inicial.

Em 1987, WILLIAMS; EDMUNDSON; REES ${ }^{66}$ citaram os valores, em MPa, do módulo de elasticidade dos seguintes materiais e tecidos: ( 1 ) cimento de fosfato de zinco $=22,4 ;(2)$ dentina $=18,6 ;(3)$ esmalte $=84,1$; ( 4 ) amálgama = 21,2; 5 ) aço inoxidável $=210$. 
BARABAN $^{7}$ fez uma revisão, em 1988, sobre a restauração de dentes tratados endodonticamente.

Cita como vantagens dos pinos intra-radiculares préfabricados, a sua confecção em uma única sessão e, quando existisse suficiente quantidade de tecido remanescente, um pino dentinário poderia ser usado, numa uma direção diferente daquela do pino intra-radicular, para garantir melhor retenção do núcleo de preenchimento. Mostrou preocupação com a estética ao preconizar para os dentes anteriores o uso da resina composta, naqueles casos em que o canal fosse muito largo para sustentar um pino intra-radicular pré-fabricado, ao invés de amálgama de prata, evitando assim o escurecimento da raiz causado pela liberação de prata pelo mesmo.

Mesmo assim, questiona o uso de resina composta como núcleo de preenchimento, pois a micro-infiltração entre o compósito e a dentina é um sério problema. Se o intervalo de tempo é breve entre a confecção do núcleo de preenchimento e a cimentação final da restauração, a microinfiltração pode ser minimizada pois as restaurações provisórias fornecem selamento adequado. Por outro lado, se o núcleo de preenchimento ficar sob condições provisórias por muito tempo, exposto aos fluidos orais, como em tratamentos restauradores extensos, micro-infiltrações podem resultar em conseqüente formação de cáries sob o núcleo de preenchimento, negando as vantagens de seu uso.

BERGMAN et al. ${ }^{11}$, realizaram um estudo retrospectivo, publicado em 1989, verificando o sucesso de tratamento de dentes tratados endodonticamente nos quais foram instalados núcleos metálicos fundidos. Examinaram 69 pacientes que receberam núcleos metálicos fundidos na Clínica de Graduação da Universidade de Umea durante o ano de 1978. Esses pacientes tiveram uma grande perda de tecido dentário nos dentes que receberam núcleos metálicos fundidos. Eram 26 homens e 27 mulheres, com média de idade de 60,2 anos. Foram instalados 39 núcleos metálicos fundidos em dentes anteriores, 40 na região de pré-molares e 17 na região de molares. Dos 96 núcleos metálicos fundidos, 49 foram colocados em coroas individuais e 47 foram instalados em dentes suportes de próteses parciais fixas. Os núcleos metálicos eram fundidos em liga 
áurea tipo III. Todos os dentes foram tratados e obturados com guta-percha, tendo sido deixado $5 \mathrm{~mm}$ de material obturador no ápice dos dentes. No reexame após 06 anos, dos 96 núcleos metálicos fundidos, 87 ou $96 \%$ foram classificados como sucesso. Dos que falharam, 06 foram de 03 próteses parciais fixas na maxila, 01 falha com uma prótese parcial fixa na mandíbula , um com uma coroa unitária na maxila e outra na mandíbula. Mesmo assim, não houve diferença significativa entre coroas unitárias e próteses parciais fixas, assim como não houve diferença entre núcleos metálicos fundidos na região anterior e na posterior.

KWIATKOWSKI; GELLER ${ }^{39}$ realizaram um trabalho clínico, em 1989, inserindo 8 unidades de núcleos intra-radiculares totalmente cerâmicos in vivo, fabricados pelo sistema Dicor (Dentsply). Todas as unidades foram instaladas em dentes anteriores, distribuindo contatos funcionais iguais ao dente adjacente. $O$ período mais longo de serviço de tais unidades foi de 16 meses, e o mais curto foi de 7 meses. Uma unidade falhou, fraturando uma semana após a inserção, possivelmente, segundo os autores, por causa do ajuste da coroa provisória. Os passos para confecção e instalação dos núcleos intra-radiculares foram realizados de maneira convencional, com o ajuste tendo sido feito no dente, permitindo assentamento passivo dos núcleos intra-radiculares cerâmicos. Foram usados cimento resinoso e adesivo dentinário, assim como agente silanizador. As coroas totalmente cerâmicas foram cimentadas com cimento resinoso dual.

Os autores sustentam que quando uma coroa metalocerâmica, com uma camada de porcelana opaca para mascarar o metal, é usada, cerca de um terço à metade do espaço disponível atua como barreira à penetração da luz, o que se torna um obstáculo à translucidez e aparência vital da restauração. Essa translucidez em dentes vitais, permite a transmissão de luz para iluminar a estrutura dental e os tecidos circundantes. A cor da gengiva sadia resulta parcialmente da luz transmitida pela estrutura dental subjacente translúcida. Dependendo do grau de severidade, a descoloração, geralmente associada com tratamento endodôntico, pode ser minimizada ou eliminada com o método de construção de núcleos intra-radiculares totalmente cerâmicos. O coeficiente de expansão térmica dos materiais cerâmicos fundidos são muito similares ao da 
estrutura dental, dessa maneira minimizando o estresse na interface radicular de dentina com o cimento resinoso.

BARKHORDAR; RADKE; ABBASI ${ }^{8}$ investigaram em 1989, o efeito de um colar metálico de $2 \mathrm{~mm}$, com $3^{\circ}$ de conicidade, na resistência de núcleos metálicos fundidos em dentes tratados endodonticamente. Os colares metálicos foram desenhados para determinar se um dente preparado pelos princípios convencionais para coroa estética completa reforçariam dentes tratados endodonticamente. Para tanto, foram selecionados 20 incisivos centrais superiores sem cáries ou fraturas. Foram divididos em 02 grupos de 10 dentes, sendo que 0 grupo I teve um comprimento de pinos intra-radiculares de $8 \mathrm{~mm}$ sem colar metálico, e o grupo II com comprimento de pinos intra-radiculares de $8 \mathrm{~mm}$ e um colar ao redor da porção cervical de $2 \mathrm{~mm}$ de comprimento, com $3^{\circ}$ de angulação, de cada lado das paredes dentinárias coronárias, totalizando $6^{\circ}$ de convergência. A espessura das paredes de dentina coronária ficou em $1 \mathrm{~mm}$ para os dois grupos, e foi sobre esta que, no grupo II, foi confeccionado um bisel ( colar) de $2 \mathrm{~mm}$. Os pinos foram fundidos em liga de ouro e cimentados com cimento de fosfato de zinco. Uma cera simulou o ligamento periodontal. Foi aplicada uma carga constante a uma velocidade de $5 \mathrm{~mm} / \mathrm{min}$., com a força incidindo em um ângulo de $135^{\circ}$ de inclinação em relação ao plano horizontal. A força foi incidida diretamente de lingual para vestibular.

Houve uma diferença estatisticamente significativa na localização da fratura entre os dentes dos dois grupos.

Do total, 05 espécimes do grupo I, sem o colar metálico, fraturaram longitudinalmente; 04 falharam obliquamente, se estendendo da junção cemento-esmalte para o terço apical, e 01 teve fratura horizontal. A média de carga de falha foi $49,6 \mathrm{Kg}$.

Nove espécimes do grupo II fraturaram, e um foi descartado por fratura da base de resina; 04 tiveram fratura no terço apical, 01 exibiu fratura horizontal e vertical, 02 separados com linha de fratura mais apical na superfície lingual e 01 teve fratura oblíqua. A média de fratura foi de $65,29 \mathrm{Kg}$. 
CHRISTEL et al. ${ }^{17}$, em 1989, analisaram que nos vários anos que se passaram pesquisas intensas pelo mundo inteiro focalizaram aumento da resistência das cerâmicas. Entre os vários mecanismos de aumento de resistência, aqueles relacionados a transformações de fase de partículas de óxido de zircônio parecem ser os mais eficientes. A resistência e acabamento de superfície tem feito com que a cerâmica estabilizada parcialmente por zircônia seja um sério candidato à reposição de articulações humanas. Esses materiais exibem transformações de fase a altas temperaturas. Em temperatura ambiente, a fase estável do dióxido de zircônio tem simetria monoclínica, mas durante o aquecimento, ela primeiro se transforma em fase tetragonal ( num intervalo de temperatura de 1000 a $1100^{\circ} \mathrm{C}$ ), depois em fase cúbica ( acima de $2000^{\circ} \mathrm{C}$ ). No entanto, mudanças notórias ocorrem em volume, associadas com essas transformações de fases: durante a transformação de monoclínica para tetragonal há uma diminuição de volume de $5 \%$, quando o dióxido de zircônio é aquecido; inversamente, um aumento de $3 \%$ no volume é observado durante o processo de resfriamento. Essa última transformação em fase monoclínica é da mesma natureza da transformação martensítica que ocorre no aço.

As mudanças de volume relacionadas a transformações de fase de tetragonal para monoclínica resultam em um material pré-estressado. A propagação de uma trinca pode liberar o estresse aos grãos vizinhos que então se transformam de uma fase metastásica estável para uma fase monoclínica. A expansão de volume associado resulta em estresse compressivo na ponta da trinca e uma energia extra é requerida para que a trinca se propague mais adiante. Dessa maneira, acredita-se que o principal mecanismo de absorção de energia é devido a transformação idêntica à martensítica, que ocorre no ponto da trinca.

Utilizando-se $0 \mathrm{Y}_{2} \mathrm{O}_{3}$ como agente estabilizador é possível produzir uma cerâmica estabilizada por ele, feita de $100 \%$ de pequenos grãos tetragonais metastásicos.

O material estudado pelos autores é obtido pela sinterização de pó de zircônia ultrafino ( média de tamanho de partículas de 0,2 $\mu \mathrm{m}$ ) com peso de $5 \%$ de $\mathrm{Y}_{2} \mathrm{O}_{3}$. Esse pó é altamente adaptado por sinterização, quando a densificação ocorre em um intervalo de $1400-1500^{\circ} \mathrm{C}$, correspondente à fase 
tetragonal do sistema $\mathrm{ZrO}_{2}-\mathrm{Y}_{2} \mathrm{O}_{3}$. A micro-estrutura final consiste em grãos de diâmetro médio de $0,5 \mu \mathrm{m}$.

Geralmente, pós ultrafinos são inadequados para compactação. Por isso, é difícil conformar componentes espessos tais como cabeças de articulações. Pressão isostática a frio é o procedimento mais aceitável para que sejam formadas peças de cerâmica parcialmente estabilizada por zircônia. A densificação pode ser atingida de duas maneiras: sinterização com ou sem pressurização + pressão isostática a quente. Esse processo consiste de 02 estágios: pré-sinterização dos componentes sem pressão até $95 \%$ da densidade teórica e subseqüente remoção de porosidades residuais em uma pressão isostática a quente em um processo complementar. Nesse procedimento, a densificação completa ocorre somente com crescimento de grãos limitados, resultando em uma melhora de resistência. Assim, a resistência dessa cerâmica é mais alta do que a da $\mathrm{Al}_{2} \mathrm{O}_{3}$.

As principais características das cerâmicas estabilizadas parcialmente por zircônia $\left(\mathrm{ZrO}_{2} / \mathrm{Y}_{2} \mathrm{O}_{3}\right)$ são: densidade $\left(\mathrm{g} / \mathrm{cm}^{3}\right)=6$; tamanho médio de grãos <05 $\mu \mathrm{m}$; microdureza (Vickers) entre 1000 e 1300; módulo de elasticidade $(\mathrm{GPa})=200$; resistência à curvatura $(\mathrm{MPa})=1200$ e resistência à fratura $\mathbf{K}_{\mathrm{IC}}$ $\left(\mathrm{mN} / \mathrm{m}^{3 / 2}\right.$ ) entre 9 e 10. A rugosidade de superfície ( Ra ) situa-se em um intervalo de $0,08-0,18 \mu \mathrm{m}$.

A quantidade de íons de zircônia liberados foi estudada através de microanálise por R-X, seguida à implantação de zircônia em osso de coelho. Não foi encontrada nenhuma difusão de íons no osso circundante.

ATMADJA; BRYANT ${ }^{4}$ examinaram, em 1990, alguns fatores que influenciam na $p$ rofundidade de polimerização de quatro resinas compostas, através de medição da dureza a diferentes profundidades da superfície. As resinas testadas: ( 1 ) P-30; ( 2 ) Heliomolar radiopaca; ( 3 ) cores cinza clara e cinza escura da Prisma-fil; e ( 4 ) cores cinza clara e cinza escura da Durafil. Foram encontradas diferenças substanciais em dureza entre as quatro resinas compostas, variando em tempo e exposição. As híbridas - com conteúdo de microcarga muito baixo - foram mais 
duras do que as resinas compostas de macropartículas, que foram mais duras do que os compósitos de micropartículas.

As quatro resinas diminuíram em dureza proporcionalmente ao aumento da espessura dos corpos de prova, mantendo o mesmo tempo de exposição à luz halógena; o mais rápido declínio de dureza, relativo à profundidade, se deu com a resina composta opaca Heliomolar ( carga pesada $-78 \%$ de massa de micropartículas ).

SORENSEN; ENGELMAN ${ }^{59}$, em 1990, pesquisaram o efeito da adaptação de um pino intra-radicular às paredes radiculares na resistência dos dentes à carga oblíqua.

Tomaram 40 incisivos centrais superiores, desbastaram suas porções coronárias, seguindo a junção cemento-esmalte, deixando-os com $15 \mathrm{~mm}$ de comprimento e os dividiram em quatro grupos, tendo sido todos preparados com ombro de $90^{\circ}$, permanecendo $1 \mathrm{~mm}$ de dentina na parte cervical.

Nos grupos 1,2 e 3 somente $1 \mathrm{~mm}$ de estrutura axial radicular foi deixada, ao nível do ombro, criando um largo canal com forma afunilada.

O tamanho do canal foi igual para todos os grupos e 0 tamanho coronário do núcleo metálico fundido foi de $7 \mathrm{~mm}$. Um pino intra-radicular de plástico Parapost foi adaptado de acordo com o que se segue, e posteriormente foi fundido, tornando-se um núcleo metálico fundido. O grupo 1 consistiu de um pino intra-radicular Parapost, sem se estender dentro do canal. Portanto, parte do canal seria preenchido com cimento, deixando o pino intra-radicular sem contato direto com as paredes radiculares; no grupo 2 foram usados pinos intra-radiculares com metal intimamente adaptados às paredes do canal, com espessura mínima de cimento; no Grupo 3 foram usados pinos intra-radiculares Parapost com metal se estendendo $2 \mathrm{~mm}$ dentro do canal, simulando uma adaptação parcial do núcleo metálico fundido; no grupo 4 foram usados pinos intra-radiculares Parapost que preencheram os canal, totalmente adaptados.

O processo de ceroplastia das coroas foi feito diretamente nos dentes, as quais foram fundidas em metal básico. Posteriormente, foram cimentadas com cimento de fosfato de zinco. Um dispositivo foi feito nas coroas para 
permitir uma carga num ângulo de $130^{\circ}$ em relação ao longo eixo do dente. A carga foi feita a uma velocidade de $2,54 \mathrm{~mm}$ por min.

Falhas ocorreram devido ao deslocamento da coroa, deslocamento do pino intra-radicular, fratura da raiz, ou fratura do pino intraradicular.

A média de valores de carga até falha foi de:

.Grupo $1-22,4 \mathrm{Kg} \pm 4,4$.

.Grupo $2-49,58 \mathrm{Kg} \pm 10,26$.

.Grupo $3-29,47 \mathrm{Kg} \pm 5,89$.

.Grupo $4-28,89 \mathrm{Kg} \pm 9,47$.

Uma análise do modo de fratura demonstrou que 17 dos 20 dentes nos grupos 2 e 3 falharam devido à fratura. Esse alto índice de fratura ocorreu em pinos intra-radiculares que se adaptaram intimamente com a configuração radicular. Nas amostras em que somente o Parapost se estendeu dentro do canal ( Grupo 1 e 4), falhas ocorreram devido à fratura do dente e falha do cimento. Em todas as 6 amostras do grupo 1 com falha de cimento ocorreu 0 entortamento dos pinos intra-radiculares. Vistos de um aspecto proximal, os grupos 2 e 3 tiveram um incidência de fratura mais alta quando comparados com o grupo 4. As fraturas do grupo 2 e 3, em que foram usados pinos intra-radiculares cônicos, envolveram mais estrutura dentária do que as dos pinos paralelos.

Esse estudo questiona a remoção adicional de estrutura dentária para acomodar pinos intra-radiculares de paredes paralelas. $O$ grupo 1, com somente $1 / 3$ dos pinos intra-radiculares em contato íntimo com os remanescentes radiculares, teve uma média de limiar de falha igual àquela do grupo 4 , onde os pinos intra-radiculares eram de lados paralelos, intimamente adaptados às paredes do canal. Ainda, uma grande quantidade de cimento circundando os 2/3 incisais dos pinos intrarradiculares não afetou o limiar de carga para falha.

Em 1992, YAMAN; THORSTEINSSON ${ }^{67}$ analisaram, em modelos de resina fotoelastica, a influência de diferentes complexos formados por materiais de preenchimento/pinos intra-radiculares na distribuição de estresse. Os pinos intra-radiculares testados foram os de forma cilíndrica e serrilhados, avaliados 
em três situações: ( 1 ) na instalação; ( 2 ) com carga vertical e ( 3 ) com carga angulada em $26^{\circ}$. No grupo 1 foram usados pinos intra-radiculares Parapost; no grupo 2, a resina composta (Concise) foi usada como núcleo de preenchimento, aliada aos pinos intra-radiculares Parapost; no grupo 3 foi usado amálgama ( Tytin ) como núcleo de preenchimento, mais pinos intra-radiculares Parapost; no grupo 4 foi utilizado núcleo metálico fundido confeccionado a partir de um pino Parapost plástico, próprio para fundição; todos os pinos intra-radiculares Parapost tinham diâmetro de 1,6mm. Foi construída uma matriz em resina própria para modelos de fotoelasticidade, com um furo no centro, onde todos os espécimes foram cimentados com fosfato de zinco. Uma matriz foi posicionada na parte coronária dos pinos intraradiculares para a confecção do núcleo de preenchimento. A parte do pino que estava inserida no bloco de resina acrílica media de $9 \mathrm{~mm}$, e a parte externa media de $5 \mathrm{~mm}$, totalizando $14 \mathrm{~mm}$. A análise foi feita num polariscópio circular, onde foram identificadas franjas nos terços cervical, médio e apical dos pinos.

Os resultados mostraram que, na inserção, os núcleos metálicos fundidos quase não criaram estresse. Os pinos intra-radiculares préfabricados nos outros grupos evidenciaram estresse no terço cervical e apical, sobressaindo-se o grupo das resinas. Durante a inserção, nenhuma diferença estatisticamente significativa foi achada entre os grupos, mas o grupo da resina criou mais estresse na região apical.

À carga vertical, o grupo 1 não mostrou estresse, enquanto todos os outros demonstraram diferenças significativas. O grupo da resina mostrou estresse similar ao do amálgama de prata e menor que os núcleos metálicos fundidos na região cervical. Todos demonstraram estresse igual no terço médio; na região apical, o de menor estresse foi o grupo dos núcleos metálicos fundidos; o grupo sem preenchimento, no entanto, causou estresse, e o da resina e amálgama de prata foram intermediários, mas todos demonstraram estresse.

Com carga de $26^{\circ}$ houve acúmulo de estresse em um só lado, resultando em uma distribuição assimétrica de estresse. Na região cervical, o estresse estava concentrado abaixo dos núcleo de preenchimento, com o grupo dos núcleos metálicos fundidos sendo significativamente mais estressante que os outros grupos. 
Concluindo, os pinos intra-radiculares pré-fabricados aliados a um núcleo de preenchimento de resina, provavelmente geram estresse nos dentes tratados endodonticamente durante sua inserção e quando submetidos a forças verticais.

LAl; JOHNSON ${ }^{40}$ afirmaram, em 1993, que o estresse gerado por uma contração de volume de $2 \%$, encontrado na polimerização das resinas compostas, é geralmente suficiente para causar tanto falha adesiva, resultando em micro-infiltração com o dente, como falha coesiva, resultando em microfratura da resina composta.

CREUGERS; MENTINK; KÄYSER ${ }^{22}$ fizeram uma metaanálise, em 1993, para revisar estudos clínicos de restaurações dentais sobre núcleos intra-radiculares. O método para meta-análise usado foi o preconizado por L'abbé et al. Uma pesquisa de literatura foi feita pelos autores, para identificar os estudos de 1970 a 1992.

Seguindo os objetivos do estudo, os critérios de inclusão e exclusão para selecionar os dados foram os seguintes: ( 1 ) a média de período de acompanhamento deveria ser de 05 anos; ( 2 ) a publicação deveria fornecer informações relevantes sobre os pacientes e o procedimento de seleção dos pacientes; ( 3 ) deveria haver informações suficientes sobre os sistemas de pinos intra-radiculares e núcleo de preenchimento; ( 4 ) deveria haver uma definição clara para o termo "falha"; ( 5 ) a publicação deveria apresentar os dados de sobrevida ( incluindo informações censuradas ) ou deveria conter informações apropriadas para calcular ou acessar dados de sobrevivência, incluindo intervalos de confiança.

Foram encontrados 16 artigos que continham dados duráveis sobre pinos intra-radiculares e núcleos de preenchimento. Três dessas publicações lidaram com o mesmo tipo de restaurações e, portanto, foram agrupadas. Referências foram feitas a relatos de estudos mais recentes. Dos 16 estudos, 11 foram excluídos para posteriores análises. Foi constatado, nesses 11 artigos, diferentes definições para "falhas". As restaurações de núcleos intraradiculares foram consideradas falhas nos casos onde um ou mais dos seguintes 
eventos ocorreram: perda de retenção ( recimentação ), inserção de um novo núcleo intra-radicular ( nova restauração ), fratura da raiz ou extração do dente. O método Kaplan e Meier foi usado para reconstruir a curva de sobrevivência dos núcleos intra-radiculares em diferentes estudos.

Como resultado, foram obtidos um ponto final de curva de sobrevivência, após 06 anos, de $81 \%$ para núcleo de preenchimento de resina composta em combinação com pinos intra-radiculares, e 91\% para os 02 estudos que incluíam núcleos metálicos fundidos. Os estudos que continham falhas nas definições de "falha" apresentaram sobrevida com taxas que variaram de 98,6\% após acompanhamento de mais de 10 anos, até $77,6 \%$ de sobrevida após um acompanhamento de 5,2 anos.

$\mathrm{NOORT}^{48}$, em 1994, fez uma análise pessoal quanto à resistência, que apesar de desejável, não é necessariamente a mais importante consideração sobre um material restaurador. Recomenda que dados de resistência sejam interpretados com cuidado e que devem ser consideradas as propriedades mais adequadas para aplicação de cada material, individualmente. Destaca, ainda, que o grande desafio dos cientistas relativo aos materiais dentários está em desenvolver um melhor entendimento entre a micro-estrutura e as propriedades desses materiais por um lado, e suas performances clínicas por outro lado.

$O$ autor destaca ainda que as falhas, ao se escolher um material de trabalho, estão relacionadas a um ou mais dos seguintes fatores: ( 1 ) estética- cor, opacidade, superfície; ( 2 ) segurança - toxicidade, carcinogenicidade, alergia e sensibilidade; ( 3 ) ambiental - química e biológica; ( 4 ) mecânica -resistência, dureza, fadiga, desgaste.

Os valores de resistência podem ser verificados de várias maneiras. Para os materiais dentais friáveis, os mais comumente usados são a resistência à tração diametral e a resistência à compressão, pois eles são facilmente conduzidos e razoavelmente reproduzíveis. Esses testes são mais úteis para monitorar, em laboratório, mudanças nas propriedades mecânicas devido a mudanças na composição ou estrutura dos materiais. Ambos os testes produzem uma distribuição de estresse interno nas amostras cilíndricas tais como combinação 
de compressão, tensão e cisalhamento e assim fornecer propriedades ambíguas desses materiais. Testes mais apropriados para tais materiais podem ser os de resistência flexural uniaxial ou biaxial, que dão informações da resistência à tração, pois esses materiais muito provavelmente falharão por um modo de tração, embora as condições de carga possam ser compressivas.

Como tais estruturas se comportarão sob aplicação de uma carga externa, dependerá não somente das propriedades mecânicas dos materiais, tais como resistência e dureza, mas também do desenho da estrutura e a quantidade de carga que é esperada para tal estrutura .

$O$ estresse que gera falhas entre uma estrutura e um substrato é calculado como uma simples média da carga à fratura dividida pela área transversa da superfície aderida.

Em 1994, CALES; STEFANI; LILLEY ${ }^{14}$ testaram a estabilidade das cerâmicas de zircônia estabilizada por Ítrio. Foram testadas as suas propriedades mecânicas e o estudo in vitro foi feito utilizando a solução de Ringer a $37^{\circ} \mathrm{C}$ a um pH 7 por vários meses. $\mathrm{O}$ módulo de ruptura foi medido de acordo com os testes de dobramento em 03 ou 04 pontos. Difração de Raios- $X$ foi empregada para determinar a quantidade de fase monoclínica formada na superfície. $O$ estudo in vivo foi feito inserindo amostras de pequeno tamanho, que substituíram articulações de ratos, coelhos e carneiros em vários intervalos de tempo. Depois de algum tempo os animais foram sacrificados e as amostras foram coletadas para análise das propriedades mecânicas. Devido ao pequeno tamanho dos espécimes, não foi possível verificar as medidas de resistência à fratura após o envelhecimento in vivo. Daí as propriedades mecânicas serem registradas pela técnica de indentação.

Nos testes após 78, 250 e 367 dias, in vitro, não houve nenhuma mudança significativa relativamente aos testes de dobramento em 03 e 04 pontos. Esses foram realizados com amostras cujas micro-estrutura e química eram controladas. As zircônias não são todas iguais. Algumas, japonesas, usadas em engenharia, quando submetidas a mudanças de temperatura entre $200-400^{\circ} \mathrm{C}$ mostraram aumento na quantidade de fase monoclínica. Degradação a baixas 
temperaturas, que revelam transformação da fase tetragonal para fase monoclínica, são mais facilmente medidas na superfície por difração de Raios-X. Maquinação, e mesmo polimento, podem causar transformação parcial na superfície. Mas, submetidas a um processo de envelhecimento na solução de Ringer por 01 ano, a $37^{\circ} \mathrm{C}$, pastilhas polidas não sofreram nenhuma transformação.

A resistência à fratura pela técnica de indentação, nos espécimes que envelheceram in vivo, mostraram que os mesmos não sofreram nenhuma modificação ao longo de dois anos.

BENNETT et al. ${ }^{10}$ analisaram, em 1994, o efeito da distância da fonte de luz e da temperatura na polimerização de resinas compostas utilizando um colorímetro; foram utilizados discos de amostras ( $6 \mathrm{~mm}$ de diâmetro $X 1,8 \mathrm{~mm}$ de espessura ) de resina composta $\mathrm{APH}$, que foram mantidos em ambiente isotérmico e polimerizados com luz visível (Demetron) por 40 segundos. A entalpia associada com a polimerização e exposição da luz foi medida $\left(\mathrm{AH}_{1}\right)$. As amostras foram então aquecidas de 0 a $250^{\circ} \mathrm{C}$ a $20^{\circ} \mathrm{C}$ por minuto, para completar a polimerização, e a entalpia para pós-polimerização ( $\left.\mathrm{AH}_{2}\right)$ foi medida. Finalmente, amostras foram expostas à luz visível por 40 segundos, para obter a $\mathrm{AH}_{3}$, tendo como variável somente a exposição de luz. Para a primeira parte desse estudo as amostras foram mantidas a $22^{\circ} \mathrm{C}$ e polimerizadas a distância de 0,1 e $3 \mathrm{~mm}$ da ponta da luz até a superfície do material. Três amostras de cada distância foram avaliadas. A segunda parte do estudo foi realizada da mesma maneira descrita acima, mas os espécimes foram polimerizados a $37^{\circ} \mathrm{C}$. Novamente três espécimes a cada distância foram avaliados. O grau de conversão foi avaliado usando uma relação do Grau de Conversão $\left(A H_{1}-A_{3}\right) /\left(A H_{1}-A H_{3}+A_{2}\right)$. Não houve diferença significativa entre os valores de dados de conversão para espécimes polimerizados a $37^{\circ} \mathrm{C}$. No entanto, o grau de conversão dos espécimes polimerizados a $22^{\circ} \mathrm{C}$ foi significativamente diferente para todas as distâncias. A média de grau de conversão a $37^{\circ} \mathrm{C}$ foi significativamente maior do que a conversão a $22^{\circ} \mathrm{C}$ para todas as distâncias. 
LIBMAN; NICHOLLS ${ }^{41}$, em 1995, realizaram um estudo investigando o efeito da presença da férula em dentes incisivos centrais superiores com núcleos metálicos fundidos e coroas totais.

Utilizaram 25 dentes humanos, divididos em quatro grupos:

Grupo controle: 05 dentes sem núcleo metálico fundido, restaurados com coroa total. Nesse grupo, o tamanho do preparo coronário foi de $6,0 \mathrm{~mm}$ de altura.

Grupo 1: 05 dentes restaurados com núcleo metálico fundido e coroa total com $0,5 \mathrm{~mm}$ de férula. O término do preparo foi localizado a $0,5 \mathrm{~mm}$ apical à parte coronária dos núcleos metálicos fundidos, tendo as coroas 7,0mm.

Grupo 2: 05 dentes restaurados com núcleos metálicos fundidos e coroa total com $1,0 \mathrm{~mm}$ de férula. O término do preparo foi localizado a 1,0mm apical ao núcleo metálico fundido, deixando o preparo com 7,5mm.

Grupo 3: 05 dentes restaurados com núcleos metálicos fundidos e coroa total com $1,5 \mathrm{~mm}$ de férula. O término do preparo foi deixado a 1,5mm apical ao núcleo metálico fundido, com tamanho de coroa de 8,0mm.

Grupo 4: 05 dentes restaurados com núcleos metálicos fundidos e coroa total com 2,0mm de férula. O término do preparo foi deixado a 2,0mm apical ao núcleo metálico fundido, permitindo tamanho de coroa de 8,5mm.

Todos os grupos foram submetidos a uma carga por fadiga de $4 \mathrm{Kg}$ em um ângulo de $135^{\circ}$, em relação ao longo eixo do dente, a uma freqüência de 72 ciclos por minuto. Essa carga, segundo os autores, está dentro dos limites fisiológicos das forças mastigatórias. Dispositivos para medir tensão foram colocados na superfície lingual de cada dente, com o objetivo de verificar a amplitude do movimento realizado pela coroa ou pelo dente. Quando o movimento da margem da coroa atingisse uma determinada amplitude, um diagrama no computador mostraria a falha, que poderia ser no cimento, dente ou coroa.

O número de ciclos para o grupo 1 foi em média de 113; para o grupo 2 foi de 1.140; para o grupo 3 de 71.651; para o grupo 4 foi de 60.045 e para o grupo controle foi de 91.208. Não houve diferença estatisticamente significativa entre o grupo 1 e 2 , e entre o 3 e 4 e o grupo controle $(p \leq .05)$. 
Os autores discutem que o ligamento periodontal não foi duplicado, a altura da coroa não foi constante, mas sugerem que deveriam ser consideradas algumas modificações em um plano de tratamento quando um dente apresentasse uma férula menor do que $1,5 \mathrm{~mm}$, tornando-se mais importante se ainda, se a restauração final for submetida a um aumento de carga, tal como em uma prótese parcial fixa ou pilar distal de uma prótese parcial removível. Aumento de coroa clínica ou extrusão ortodôntica poderiam aumentar o tamanho da férula.

MENTINK et al. ${ }^{44}$, em 1995, citaram que um dos problemas na fabricação de núcleo de preenchimento de resina é a incorporação de bolhas. Isso, segundo os autores, diminuiria rapidamente as propriedades desejáveis desses materiais. Assim, eles realizaram um estudo para investigar o efeito de duas diferentes técnicas de manipulação na incorporação de porosidades nos núcleos de preenchimento em uma situação clínica simulada.

Os autores usaram dentes molares humanos, com tratamento endodôntico, e duas resinas compostas, sendo uma autopolimerizável ( Clearfil - Kuraray ) e a outra fotopolimerizável ( Photo core - Kuraray ). Uma técnica utilizou inserção com um instrumento manual ( Lustra $\mathrm{N}^{\circ} 3$, Ash), e a outra seringa ( Hawe-Neos ). Da amostra, 20 dentes receberam pinos intra-radiculares e os outros 20 não receberam nenhum pino intra-radicular. As amostras foram seccionadas para análise.

O resultado do teste demonstrou que uma porcentagem mínima de bolhas superficiais foi registrada na série de amostras que usou a resina autopolimerizável com pino intra-radicular na técnica da seringa. O percentual mais alto de bolhas foi encontrado na resina autopolimerizável inserida pela técnica manual. A técnica de inserção manual de resina composta fotopolimerizável foi significativamente inferior, ou seja, exibiu mais bolhas do que a técnica de inserção com a seringa. A colocação de pinos intra-radiculares não afetou as diferentes técnicas. A inserção de resina composta, nesse estudo, pela técnica manual, causou incorporação de bolhas em $95 \%$ dos corpos, independente do tipo de resina. 
UNTERBRINK; MUESSNER ${ }^{64}$, em 1995 examinaram o efeito da variação da intensidade da luz halógena nas seguintes características de dois sistemas restauradores baseados em resinas compostas: ( 1 ) a formação de fendas marginais em cavidades dentinárias, ( 2 ) o desenvolvimento de resistência e módulo de elasticidade, e profundidades de polimerização. Foram escolhidas duas marcas de resinas compostas ( Tetric e Z-100 ), variando o tipo de sistema adesivo dentinário ( Syntac - Ivoclar e Scothbond multipurpose - 3M ) e a intensidade de luz ( Baixa intensidade - Vivalux, e alta intensidade - Visilux ).

Os autores usaram dentes bovinos incisivos, que foram imersos em resina epóxica com a superfície vestibular orientada horizontalmente. $O$ esmalte vestibular foi removido e a superfície dentinária foi deixada polida e plana. Cavidades com diâmetros de 3,2 $\pm 0,2 \mathrm{~mm}$ e profundidade mínima de 2,5mm foram confeccionadas. Um total de 48 dentes foram aleatoriamente divididos em 8 grupos. Das cavidades, 12 foram restauradas com cada combinação restauradora, subdividida em dois grupos de seis, polimerizados com uma lâmpada de alta intensidade ( Visilux 2=450 $\mathrm{mWcm}^{-2}$ ), e uma lâmpada de baixa intensidade ( Vivalux $=250 \mathrm{~mW} \mathrm{~cm}^{-2}$ ). Os agentes dentinários Syntac, e Scotchbond MP foram aplicados de acordo com o fabricante e polimerizados por 40s. Os compósitos restauradores ( Tetric e Z100 ) foram aplicados em uma porção única e adaptada a eles uma tira matriz. O tempo de polimerização foi de 40s. As amostras foram imediatamente colocadas em água a $37^{\circ} \mathrm{C}$ por $55 \pm 5 \mathrm{~min}$, para permitir a contração de polimerização.

A resistência flexural e o módulo de elasticidade foram determinados nos espécimes 30min após a polimerização e, após $24 \mathrm{hs}$, submetidos a alta e baixa intensidade de luz $(n=10)$. A contração volumétrica dos compósitos foi determinada pelo método de densidade em quatro períodos de tempo: 05min, 01h, 24hs e 07 dias. Foram testados grupos para as diferentes intensidades de luz e armazenamento úmido comparado a armazenamento seco $(n=10)$. Exceto para o tempo real de teste, as amostras foram armazenadas a $37^{\circ} \mathrm{C}$. Quatro intervalos de tempo foram selecionados para prover alguma visão na taxa de polimerização.

Os perfis de Dureza Vicker, depois de $24 \mathrm{hs}$ de armazenamento, com intensidades de luz variáveis, foram determinados. Um molde 
de aço com $8 \mathrm{~mm}$ de diâmetro por $6 \mathrm{~mm}$ de altura foi colocado em uma superfície negra preenchido de resina, e esta foi polimerizada. Essa amostras foram colocadas imediatamente, após 40 s de polimerização por luz, em água a $37^{\circ} \mathrm{C}$. Vinte e quatro horas depois, essas amostras foram imersas em resina epóxica, então seccionadas através do centro do cilindro. Assim, a dureza interna foi medida ao invés da dureza superficial.

A Tetric apresentou variações nos valores de Módulo Flexural de 5,9 GPa após 30min. com a luz de baixa intensidade a 11,6Gpa após 24hs com a luz de alta intensidade; apresentou uma resistência flexural de 83MPa após 30min com luz de baixa intensidade a 145MPa com luz de alta intensidade após 24hs. Não houve nenhuma diferença estatística significante entre a luz de baixa e a luz de alta intensidade com relação à dureza interna das resinas compostas testadas para uma profundidade de $4,5 \mathrm{~mm}$. Os autores sugerem que as luzes usadas no processo de polimerização de resinas são muito altas, e são recomendadas quase que universalmente. Geralmente essas recomendações são baseadas na profundidade de polimerização e propriedades físicas que as resinas exibem. Os autores sugerem que os diversos outros autores falham ao não considerarem as possíveis influências negativas das luzes de alta intensidade no desenvolvimento de estresse.

HUYSMANS; VARST ${ }^{32}$ tentaram estimar, em 1995, a longevidade para restaurações feitas com pinos intra-radiculares/núcleo de preenchimento ( resinas compostas e amálgama de prata ), quando submetidos a cargas clínicas relevantes, conseguidos da integração de diferentes métodos de engenharia, incorporando resultados experimentais de testes quasi-static e fadiga. Assim, os autores conseguiram estimar que esses materiais conseguiram suportar cargas mecânicas correspondentes a uma sobrevida de 5 a 15 anos.

COHEN et al. ${ }^{18}$ analisaram, em 1996, o limite de carga até fratura para quatro materiais de núcleo de preenchimento diferentes ( amálgama de prata -Tytin; Resina composta reforçada por titânio - Ti-Core; lonômero de vidro reforçado por prata - Ketac-Silver; cimento de ionômero modificado - G-C Miracle 
Mix ) suportados por cinco diferentes desenhos de pinos intra-radiculares ( FlexiPost; Flexi-Flange, Parapost, AccessPost e C-Post ).

Entre incisivos e pré-molares, 200 dentes unirradiculares foram usados. Os pinos intra-radiculares foram cimentados com cimento de fosfato de zinco. Uma banda matriz de cobre foi usada para conter os núcleo de preenchimento, padronizando a altura do preenchimento em $6 \mathrm{~mm}$. Todos os dentes foram preparados deixando ângulo de convergência de 6 a $8^{\circ}$ entre as paredes. Cada grupo foi composto de 10 dentes. Os materiais de núcleo de preenchimento foram manipulados e inseridos de acordo com os fabricantes. Para o amálgama e a resina composta nenhum agente de adesão foi usado. Para os ionômeros, as paredes dentinárias foram tratadas com ácido poliacrílico a $40 \%$, por 15 segundos, seguido de lavagem com água por 30 segundos. Os conjuntos foram posicionados numa máquina de teste a $45^{\circ}$ no sentido vestíbulo-lingual e sujeitos a uma carga a velocidade de $0,635 \mathrm{~cm} / \mathrm{min}$ até fratura. A falha foi registrada quando o núcleo de preenchimento era deslocado da cabeça do pinos intra-radiculares ou quando 0 fratura do dente ocorreu. Nenhuma fratura ou falha de pinos intra-radiculares foi observada. Antes do teste, os espécimes foram armazenados em umidade de $100 \%$, numa temperatura de $37^{\circ} \mathrm{C}$ por sete dias.

Os resultados mostraram que o grupo de amálgama/Parapost exigiu a maior carga para fraturar, seguido de perto pelo Flexipost/Ti-Core e Flexi-Flange/Ti-Core. Não houve diferença significativa entre esses dois grupos. O grupo que apresentou o pior resultado foi o Parapost/Ketac-Silver. Interessante observar nesse estudo que ele representa o pior cenário em que um núcleo de preenchimento pode falhar, como o pino intrarradicular suportando-o. Todos as falhas ocorreram quando o núcleo de preenchimento ou o dente fraturou. Nenhuma falha nos pinos intra-radiculares foi observada. A maioria das falhas ocorreu nos núcleo de preenchimento ( $79 \%$ ), e $21 \%$ foi de fratura dos dentes.

Os autores citaram que a resistência à compressão do TiCore é de 41,131psi ( $284 \mathrm{MPa}$ ), e a resistência à tração diametral é de 5,219psi ( $36 \mathrm{MPa}$ ). A dentina apresenta uma resistência à compressão de 43,1psi ( 297MPa ), e a resistência à tração diametral é de 6,000psi (41MPa ). A resistência à compressão e a resistência à tração diametral do Ketac-Silver é de 16,697 
(115MPa ) e 1,814psi ( $10 \mathrm{MPa}$ ) respectivamente. A resistência à compressão e a resistência à tração diametral do G-C Miracle são respectivamente 14,197 ( 98MPa ) e 1,408psi ( $10 \mathrm{MPa}$ ).

BURGESS et al. ${ }^{13}$, em 1996, num artigo de revisão, destacam que o desempenho das resinas compostas como material restaurador tem melhorado significativamente nos últimos anos, por causa da estabilidade de cor, resistência ao desgaste, resistência mecânica, radiopacidade e percentual de cura das resinas compostas. As resina compostas são compostos por um agente de carga, um agente silanizador para aderir a carga à matriz de resina e a matriz resinosa. Carga é adicionada às resinas compostas para controlar sua manipulação clínica, aumentar a resistência, diminuir a contração e reduzir o desgaste à abrasão.

HOLMES; DIAZ-ARNOLD; LEARY, ${ }^{31}$ em 1996, citaram em trabalho de Modelo de Elemento Finito os valores para módulo de elasticidade das diversas estruturas dentais e alguns materiais em GPa: dentina = 18,6; cemento $=18,6$; ligamento periodontal $=0,0689$; osso cortical $=13,7$; osso trabecular =1,37; gengiva $=0,003$; ouro fundido $=96,6$; porcelana $=69$; cimento de fosfato de zinco $=22,4$. Os autores simularam a inserção de um núcleo metálico fundido em um dente cujo remanescente dentinário permitia a confecção de uma férula de $2 \mathrm{~mm}$ na parte coronal. O estudo demonstrou que o pico compressivo e estresse por tração ocorreram no terço coronário da dentina. $O$ pico de estresse de cisalhamento ocorreu adjacente ao pino intra-radicular no terço médio da raiz. A magnitude do estresse de cisalhamento foi influenciado pelo tamanho do pino intraradicular. Com o aumento do pino intra-radicular, ocorria diminuição o estresse de cisalhamento no terço médio da raiz.

CARVALHO et al. ${ }^{15}$ fizeram uma revisão de literatura, em 1996, abordando a contração de polimerização que ocorre nas resinas compostas. A resistência desses materiais é basicamente dependente da composição dos monômeros, conteúdo de carga, grau de conversão e cadeia cruzada do polímero resultante. São mais fortes quando moléculas de BIS-GMA são usados como 
monômero principal. O grau de conversão pode ser maximizado pela inclusão de alto percentual ( 40-50\%) de diluentes ( TEGMDMA ), mas isso é acompanhado de uma aumento significante de contração ( $1,5-3 \%$ em volume ). A contração de polimerização pode criar forças de contração que podem quebrar a adesão desta com as paredes de uma cavidade.

O papel da configuração de uma cavidade ( fator C ) no desenvolvimento de estresse de polimerização é crucial. Se a falha coesiva do material é desconsiderada, e se as paredes da cavidade são consideradas rígidas, a única fonte disponível para aliviar o estresse de contração de polimerização é a deformação elástica do material e o escoamento das superfícies livres e não aderidas. Geralmente, quanto menor superfície de área livre, sem adesão, existe na cavidade, menor será a habilidade da resina escoar e, portanto, maior o estresse de contração de polimerização nas superfícies aderidas.

Em geral, a resistência de adesão dos adesivos dentinários são avaliados depois de, no mínimo, 24 horas. A performance clínica desses sistemas adesivos pode ser melhor avaliada após algum tempo de acompanhamento; apresenta valores menores após períodos de semanas a meses, quando comparados à resistência após 24hs. A resistência de adesão de alguns sistemas resinosos autopolimerizáveis à dentina tendem a aumentar significativamente dos primeiros minutos após adesão até $24 \mathrm{hs}$. Isso porque as resinas ativadas quimicamente têm um processo vagaroso de polimerização. Uma polimerização completa é necessária para atingir sua resistência mecânica máxima e, portanto, resistência adesiva máxima. As características mecânicas de uma resina composta, medida perto da interface aderida com a dentina, são fortemente relacionadas com as forças de cisalhamento necessárias para quebrar essa adesão.

Embora os sistemas adesivos atuais possam gerar alta resistência de adesão à dentina ( $20-30 \mathrm{MPa}$ ), isso é obtido usualmente após 24hs com superfícies de dentina planas, onde o fator-C é baixo. Se a mesmas resinas pudessem ser testadas imediatamente após a adesão em cavidades de configurações diferentes, provavelmente, sua resistência de adesão seria muito menor. Se uma pequena fração da superfície aderida é rompida durante a polimerização das resinas, a retenção das resinas compostas pode ser 
significantemente afetada; o selamento da restauração pode ser comprometido e levar a conseqüências clínicas indesejáveis. Essa hipótese também pode explicar a falta de correlação entre a resistência de adesão e infiltração marginal. Para se atingir uma boa adesão dentinária, as forças de contração de polimerização devem ser minimizadas e a adesão à dentina ser maximizada. Preenchendo uma cavidade, em forma de caixa, regionalmente, em vários incrementos, o clínico pode diminuir grandemente o fator-C.

Os autores também citaram que as resinas autopolimerizáveis são mais porosas devido à incorporação de bolhas de ar durante a manipulação. A presença de bolhas de ar diminui o estresse de polimerização, mas por outro lado piora as propriedades mecânicas da resina.

DAVIDSON; FEILZER ${ }^{23}$, em 1997, fizeram revisão sobre os efeitos da modulação do início da fotopolimerização nas resinas compostas. Destacam que uma recente abordagem concebida para permitir à restauração alguma liberdade de movimento entre as paredes da cavidade e o centro da contração, consiste de uma conversão inicialmente reduzida do material resinoso nas áreas mais profundas da restauração. Em materiais fotopolimerizáveis, isso pode ocorrer em alguma extensão por causa das limitações na penetração da luz. Experimentalmente, foi demonstrado que atrasar a reação de polimerização causará menos dano à interface da restauração e a cavidade. Sob certas condições, esse retardo na reação de polimerização, pela redução de intensidade de luz, não tem uma influência contrária na taxa de conversão final e, por conseguinte, nas propriedades mecânicas da restauração.

Quanto à absorção de água, até que resinas sem contração de polimerização não cheguem ao mercado, pode ser possível compensar essa contração por meios de mecanismos adicionais de expansão. Um mecanismo geralmente citado como compensador é o fenômeno de absorção de água pelas resinas compostas. Embora essa expansão possa levar a um relaxamento substancial do estresse de contração de polimerização, o efeito de absorção de água é tardio. As superfícies da restauração devem estar expostas na cavidade bucal e o resultado desse fenômeno é desconhecido a longo prazo. 
DIETSCHI; ROMELLI; GORETTI ${ }^{25}$, em 1997, estudaram as diferentes interfaces entre restaurações e pinos intra-radiculares utilizando adesivos, feitas com diferentes sistemas de pinos intra-radiculares, depois de teste de fadiga não-destrutivo. Os grupos de sistemas de pinos intra-radiculares investigados foram: ( 1 ) Komet ( Komet ER Brasseler ), com cabeça de titânio recoberto por uma camada de agente opacificador e corpo jateado, forma cônica ,cabeça em forma de bola, com módulo de elasticidade=110; ( 2 ) Cera ( Cerametric - Dentsply ) feito de titânio coberto com plasma de alumínio de forma cônica com módulo de elasticidade $=110$; ( 3 ) Zircon ( Dentsply ) feito de zircônia sinterizada estabilizada por dióxido de ítrio e jateada com óxido de alumínio, de forma cilíndrica com módulo de elasticidade = 200; ( 4 ) Compo ( Composipost RTD ) feito com fibras de carbono embebidos em resina epóxica, de paredes paralelas, com degraus e resistência à tração $=90$ e flexural $=8 ;(5)$ Exp (Experimental) feito de fibras reforçadas por resina epóxica, de paredes paralelas, com degraus, resistência flexural e à tração de 8,9 e 60 , respectivamente. $O$ autor cita o módulo de elasticidade da dentina coronária $=2,4-2,7 \times 10^{6} \mathrm{psi}=16,5-18,5$ $\mathrm{GPa}$; e o da dentina radicular $=18 \mathrm{GPa}$.

Os autores utilizaram 40 incisivos e caninos superiores perdidos por razões periodontais, sem fraturas e não tratados endodonticamente. Uma obturação de canal sem eugenol foi utilizada. As coroas foram reduzidas até a junção cemento-esmalte a fim de que fossem obtidas somente superfícies dentinárias para procedimentos adesivos. As raízes foram preparadas para colocação de pinos intra-radiculares usando-se as recomendações dos fabricantes. Exceto para o grupo em que se utilizou o sistema Composipost, os canais radiculares foram tratados com auto ataque ED Primer ( Kuraray ), antes da inserção passiva dos pinos intra-radiculares no canal, ora preenchido com cimento resinoso ( Panavia $21 \mathrm{EX}$, Kuraray ). Um isolante gel foi usado para permitir presa do cimento. A dentina remanescente foi atacada usando-se ácido fosfórico a 37\% ( Ultradent ), por 10 segundos, antes da aplicação do Scothbond multipurpose primer e adesivo. O núcleo de preenchimento coronal foi feito usando-se uma resina híbrida autopolimerizável modificada por Titânio ( Ti-Core ). 
Para as amostras do Composipost, as raízes foram primeiramente condicionadas por 30 segundos empregando-se um ácido etilenodiaminotetracético ( EDTA ), e uma camada de resina não polimerizada foi aplicada ( Sealbond). Os núcleo de preenchimento foram feitos usando-se uma resina autopolimerizável reforçada por fibras ( Resilient).

Os espécimes foram montados em um cilindro de borracha, permitindo aos dentes movimento junto com o dispositivo montado em $45^{\circ}$ em relação a eles. Todos os espécimes foram submetidos sucessivamente a 250.000 ciclos de carga mecânica, numa força de $70 \mathrm{~N}$ a $1,5 \mathrm{~Hz}$ de freqüência. Seguido à carga mecânica, os espécimes foram submetidos a 5000 ciclos térmicos de $01 \mathrm{~min}$ cada em intervalos de $5-55^{\circ} \mathrm{C}$.

As amostras foram seccionadas. Utilizou-se microscópio eletrônico de varredura numa resolução de 250X. As seguintes superfícies internas foram estudadas: ( 1 ) a interface entre o material restaurador coronário e a cabeça do pino intra-radicular; ( 2 ) a interface entre o material restaurador e a dentina coronária; ( 3 ) a interface entre o agente cimentante com o pino intra-radicular, ( 4 ) a interface entre o agente cimentante com a dentina radicular. Os dois parâmetros de avaliação considerados foram "continuidade" e "espaços internos" para caracterizar cada porção das interfaces. O percentual de interface dente/restauração sem espaços ( relativa ao comprimento total da interface ) foi então calculado. A ocorrência ou ausência de fratura radicular foi registrada e marcada. A micromorfologia da interface com a dentina foi observada em alta resolução, para determinar, quando presente, a localização da fratura na superfície dentinária, a camada híbrida e o agente cimentante ou camada de compósito restaurador. A espessura do cimento foi registrada no meio do comprimento do pino intra-radicular em cada lado dos cortes. Uma média da integridade das interfaces e espessura de cimento foi calculada de quatro seções de cada espécime.

Analisando-se a interface núcleo de preenchimento/pino intra-radicular e pino intra-radicular/agente cimentante, a interface núcleo de preenchimento/pino intra-radicular não apresentou nenhum defeito de adesão. $\mathrm{Na}$ interface pino intrarradicular/agente cimentante houve deslocamento de $10,75 \%$ para o grupo dos pinos intrarradiculares de zircônia; na interface núcleo de 
preenchimento/dentina, o percentual de adesão em continuidade variou de 44,88\% no grupo Composipost a $83,88 \%$ no grupo Komet. O grupo Komet apresentou valores mais altos de continuidade de interface comparado às restaurações de Zircon e Experimental.

Os autores discutiram que somente as interfaces entre 0 material restaurador e a dentina demonstraram defeitos significantes; entre os cinco sistemas de pinos intra-radiculares adesivos testados ( Komet ER, Cerametric Prototype, Composipost, pino de Zircônia experimental e pino reforçado por resina experimental ), o pino intra-radicular Komet ER exibiu a maior continuidade entre as interfaces coronais e radiculares, embora os espécimes nesse grupo apresentassem fraturas. O pinos intra-radiculares de zircônia experimentais tiveram uma influência adversa na adaptação entre o núcleo de preenchimento e pino intraradicular/dentina, provavelmente resultado de sua alta rigidez; também é improvável que o cimento 10-Meta tenha desenvolvido uma adesão com a cerâmica, ou que as micro-retenções, fornecidas na zircônia, densamente sinterizada por partículas jateadas, tenha sido totalmente eficiente, embora esse procedimento condicionador tenha provado ser o mais eficiente dentre os possíveis; as propriedades mecânicas do Composipost, que são próximas às da dentina, pareceram ter sido benéficas nesse estudo; o uso de agentes de adesão dentinários pareceu ser mandatário para melhorar a adesão dos materiais usados à dentina.

COHEN et al. $^{20}$ compararam, em 1997, a resistência à fratura de ionômero de vidro modificado ( Advance), amálgama de prata ( Tytin ) e resina composta modificada por titânio ( Ti-Core ).

O estudo consistiu na utilização de dentes unirradiculares com pinos intra-radiculares pré-fabricado Flexi-Flange, ou sem pinos intraradiculares, com a parte coronária reconstituída com um dos três materiais.

Foram usados 60 dentes unirradiculares recém-extraídos. Foram divididos em grupos de 10. O grupo I consistido de amálgama de prata/pino intrarradicular; o grupo II de amálgama de prata/sem pino intra-radicular; o grupo III de resina composta/com pino intrarradicular; o grupo IV de resina composta/sem pino intra-radicular; o grupo V lonômero de vidro/com pino intra-radicular e o grupo 
VI de ionômero de vidro/sem pino intra-radicular. Trinta dentes foram desgastados até a junção cemento-esmalte, deixando dentina remanescente no lado vestibular. Os canais foram obturados e os remanescentes coronários foram preenchidos com os materiais de preenchimento. Os outros 30 dentes foram desgastados até a junção cemento-esmalte e preparados para receber pinos intra-radiculares Flexi-Flange $n^{\circ} 1$ de aço inoxidável, cimentados com cimento de fosfato de zinco. Foi utilizado um agente de adesão para os núcleos de preenchimento. Cada um dos núcleos de preenchimento foi deixado com $4,5 \mathrm{~mm}$ de altura. Os dentes foram montados em bases de resina acrílica. Todos os grupos foram armazenados em umidade de $100 \%$, em temperatura ambiente, por uma semana antes do teste. Foi aplicada uma força num ângulo de $45^{\circ} \mathrm{com}$ a face lingual, a uma velocidade de $0,63 \mathrm{~cm}$ por min até ocorrer fratura. Esse estudo, segundo os autores, identifica o pior cenário onde uma coroa é perdida, e o núcleo de preenchimento com ou sem um pino intra-radicular poderia falhar.

Todas as falhas ocorreram por fratura do núcleo de preenchimento ou do dente. Nenhuma fratura foi observada nos pinos intraradiculares neste estudo.

Os resultados mostraram que a resina composta modificada por titânio com ou sem pino intra-radicular teve um resultado significativamente melhor que os outros materiais, sendo que o amálgama de prata teve desempenho melhor que o ionômero de vidro, mas não estatisticamente significativo. Em todos os grupos não houve diferença estatisticamente significativa quando se avaliou a presença ou não de pino intra-radicular.

Em 1997, BAHARAV et al. ${ }^{5}$ analisaram o efeito do tempo de irradiação nas propriedades de tensão de dureza e resistência das resinas compostas.

Os autores utilizaram materiais que continham grande quantidade de partículas de carga, e que eram muito friáveis. Assim, os escolhidos foram a Herculite XRV ( Kerr ), Brilliant ( Coltene ) e P-50 ( 3M ).

Um molde cilíndrico de politetrafluoretileno com $2 \mathrm{~mm}$ de espessura, com uma extensão de $4 \mathrm{~mm}$, foi preenchido com resina composta, 
tampado com fitas de poliéster nas extremidades. A ponta da unidade de luz ativadora foi colocada em cima da fita de poliéster. O material era irradiado por 20, 40, 80 ou 120 segundos. Num total de 120 espécimes, dez espécimes foram preparados para cada combinação de material e tempo. Antes do teste, os corpos de prova foram armazenados em $100 \%$ de umidade, a $37^{\circ} \mathrm{C}$, por 24 horas.

Os corpos de prova foram submetidos a tensão diametral com uma máquina de teste universal a uma velocidade de $0,5 \mathrm{~cm}$ por $\min$.

Os materiais não diferiram significantemente entre si quanto à resistência à tensão diametral, mas diferiram quanto à dureza. Houve diferença significativa considerando o tempo de irradiação entre todos os corpos, quando se comparou a irradiação por 20 segundos com os outros tempos, ou seja, irradiar por 40, 80 ou 120 segundos não alterou a dureza significativamente. Quanto à dureza, a resina P-50 mostrou diferença significativa em relação tanto à Herculite XRV quanto à Brilliant, para todos os tempos de irradiação estudados. O aumento do tempo de irradiação influenciou significativamente a dureza da resina Brilliant.

FRADEANI; AQUILANO ${ }^{26}$, em 1997 investigaram o comportamento clínico de 144 coroas de porcelana pura, fabricadas pelo método de fundição, da marca Empress, em sua clínica privada. A amostra estudada incluiu 55 pacientes ( 36 mulheres e 19 homens ), com média de idade de 38,5 anos. Pacientes com periodontite, parafunção severa, séria inflamação gengival, higiene oral pobre ou alto índice de cáries foram excluídos do tratamento e do estudo. Foram incluídos 51 incisivos centrais, 38 incisivos laterais, 12 caninos, 28 pré-molares e 15 molares. Foram colocadas 108 coroas em dentes tratados endodonticamente, e as restantes 36 coroas foram colocadas em dentes vitalizados. Os dentes tratados endodonticamente tiveram reconstituição coronária de amálgama de prata, resina composta ou núcleos metálicos fundidos de ouro. As coroas foram atacadas por ácido hidrofluorídrico a 4,5\% na sua parte interna. Utilizou-se agente silanizador. Em 69 coroas ( $48 \%$ ) foi usado cimento Dual e em 70 coroas ( $49 \%$ ) Variolink, ambos resinosos, para cimentação. Em 05 ( $3 \%$ ) coroas foi usado cimento de fosfato de zinco para cobrir o núcleo metálico fundido, e conseguir adequada coloração final para a coroa. 
Como critérios de avaliação foram observados a cor, descoloração marginal, cáries recorrentes, contorno e integridade marginal.

O resultado de uma avaliação de no mínimo 06 meses e no máximo 68 meses com um período médio de 37,1 meses evidenciou que 5 das 144 coroas falharam; duas falhas ocorreram por causa da fratura do núcleo de preenchimento feito em resina; as outras três falhas ocorreram por fratura das coroas de cerâmica, sendo uma em um incisivo central com uma espessura lingual de cerâmica de $0,9 \mathrm{~mm}$. As outras duas fraturas ocorreram em segundos molares, onde os autores relataram ter espessuras de 1,2 e 1,3mm em algumas áreas dessas duas coroas. Quatro das restaurações foram substituídas por coroas metalocerâmicas.

Utilizando-se o método Kaplan e Meier, a taxa de sucesso estimada após 6 anos seria de 95,35\%.

Nenhuma diferença estatisticamente significativa foi encontrada considerando-se insucesso de dentes anteriores e posteriores de acordo com a análise de Kaplan e Meier.

COHEN et al. ${ }^{19}$ investigaram, em 1997, o efeito de cargas cíclicas em quatro materiais usados para núcleo de preenchimento: resina composta modificada por titânio Ti-Core, lonômero de vidro modificado por prata Ketac-Silver, amálgama de prata Tytin, e um ionômero de vidro modificado G-C Miracle Mix, suportados por cinco pinos intra-radiculares pré-fabricados: Flexi-Post, Flexi-Flange, ParaPost, Vlock e AccessPost. Os núcleo de preenchimento não foram cobertos por coroas artificiais e cargas foram aplicadas diretamente sobre os núcleo de preenchimento.

Foram usados 100 espécimes divididos em 05 grupos dos diferentes pinos intra-radiculares, com 05 pinos intra-radiculares para cada núcleo de preenchimento. Os dentes foram reduzidos até a junção cemento-esmalte. Todos os dentes foram medidos em suas dimensões vestíbulo-lingual, mésio-distal, coronoapicalmente e na junção cemento-esmalte. Os preparos para os pinos intraradiculares foram feitos conforme as instruções dos fabricantes. Somente pinos intra-radiculares de aço inoxidável foram usados. Todos foram cimentados com 
cimento de fosfato de zinco, que foi deixado cristalizar por 01 hora. As estruturas remanescentes foram atacadas por ácido, para inserção da resina composta e amálgama de prata. A utilização de um adesivo ( Scothbond Multipurpose ) e a fabricação de cada núcleo de preenchimento foram feitas de acordo com as instruções do fabricante.

Um bisel de $30^{\circ}$ foi feito na região vestibular de cada dente, para permitir a instalação de transdutores, que foram colocados em blocos de resina acrílica. Foram armazenados em $100 \%$ de umidade por uma semana. Cada combinação foi colocada em um dispositivo que permitiu uma carga de 22,2N ( 5 libras ) num ângulo de $30^{\circ}$ ao eixo vestibulo-lingual por 4.000 .000 ciclos, até que ocorresse falha tais como fratura do dente ou do núcleo de preenchimento ou do pino intra-radicular. A taxa de repetição seria de 03 por segundo. Um outro dispositivo garantiria que se o núcleo de preenchimento ou o pino intra-radicular ou o dente fraturassem as cargas seriam interrompidas automaticamente.

Todos os complexos que utilizaram as resinas compostas e amálgama de prata resistiram aos 4 milhões de ciclos. Todos os espécimes com lonômero de vidro modificados com prata falharam antes dos 4 milhões de ciclos, assim como aqueles que utilizaram cimento de ionômero de vidro modificado. Existiu diferença significante entre os materiais de núcleo de preenchimento, mas não entre os pinos intra-radiculares.

Em 1998, PICONI et al. ${ }^{50}$ testaram a pureza química e radioquímica, e a estabilidade hidrotermal, depois de envelhecimento in vivo e in vitro e esterilização em vapor, através da porosidade superficial das cerâmicas de policristais tetragonais de zircônia estabilizadas por Ítrio. Os resultados foram que depois de envelhecimento em solução de Ringer a $37^{\circ}$ a resistência no teste à curvatura nos quatro pontos não se modificou substancialmente. Nenhuma corrosão foi observada in vivo ( tíbia e fêmur de coelhos da Nova Zelândia ) após seis meses ou um ano de inserção. Da mesma maneira foi observado contato íntimo entre a cerâmica e o osso. Foi observada pequena rugosidade superficial neste teste. Ao ser submetido ao tratamento hidrotérmico, a $120^{\circ} \mathrm{C}$ em atmosfera úmida, houve pouca influência na resistência à curvatura, reduzindo esta magnitude em $25 \%$. Isso indica 
que, sob esterilização, um pino de zircônia poderia perder até $25 \%$ de sua resistência. Essas características tornam a cerâmica parcialmente estabilizada por zircônia apropriada para uso em ortopedia.

SORENSEN et al. $^{58}$ realizaram um experimento clínico prospectivo, em 1998, onde avaliaram a longevidade de 75 coroas Empress totalmente cerâmicas. Tiveram como objetivos secundários a metodologia de cimentação adesiva e efeitos colaterais potenciais. Um total de 75 coroas totalmente cerâmicas Empress foram instaladas em 33 indivíduos. Suas idade variaram de 17 a 69 anos. Das coroas colocadas 47 foram em dentes anteriores, 15 em pré-molares e 13 em primeiros molares. Cimento dual foi usado para cimentar . Na revisão de 03 anos, uma coroa num molar fraturou ( com 27 meses de uso ). Dos dentes recobertos com coroas, 53 eram vitalizados, com pacientes relatando sensibilidade pós-cimentação a líquidos gelados em 03 coroas, ou 5,6\%. No entanto, nenhum dos dentes restaurados necessitou de tratamento endodôntico. Duas restaurações $(2,7 \%)$ exibiram leve micro-infiltração na interface dentina-cemento.

Também em 1998, AHMAD ${ }^{1}$ descreveu uma técnica de confecção de núcleos intra-radiculares tendo como pinos intra-radiculares os de zircônia ER-Cerapost ( Brasseler ). Reduzia-se totalmente o remanescente coronário dos dentes utilizados, in vivo, para eliminação da dentina escura que, segundo o autor, poderia influenciar na cor da coroa totalmente cerâmica. Sendo a forma do pino cilíndrica, o autor confeccionou uma caixa na entrada do conduto com o intuito de prevenir a rotação do núcleo intra-radicular. Para reconstruir a parte coronária, o autor utilizou porcelana reforçada com leucita fundida Empress. O autor preconizou técnica indireta para confecção do núcleo intra-radicular, utilizando o próprio pino intra-radicular como material de moldagem junto com um elastômero. Após a moldagem, foi feito um enceramento da porção coronária, removida a cera e fundida, uma vez que a diferença de coeficiente de expansão entre os dois materiais não permitiria a inclusão e posterior fundição da parte coronária. Após a cimentação do pino intra-radicular com cimento resinoso, o núcleo de preenchimento fundido em cerâmica reforçada por leucita foi cimentado com cimento resinoso sobre o 
remanescente coronário do pino intra-radicular e, posteriormente, foi instalada coroa em porcelana pura Empress em cada elemento, conseguindo-se assim, as melhores características estéticas desses materiais.

VARGAS; COBB; SCHMIT ${ }^{65}$, em 1998, destacam que a polimerização adequada é um fator crucial para se obterem propriedades físicas e performance clínica ótimas das resinas compostas.

Os problemas associados com uma polimerização inadequada incluem propriedades físicas inferiores, solubilidade no ambiente oral e aumento da micro-infiltração resultando em cáries e problemas pulpares. As resinas fotoativadas necessitam intensidade de luz para serem adequadamente polimerizadas.

Quando a luz passa através do compósito, ela é absorvida e difundida, atenuando a intensidade e reduzindo a efetividade da luz para a polimerização da resina à medida que a profundidade aumenta.

Os fatores que afetam a profundidade de cura da resina composta fotoativada incluem: tamanho, tipo e carga da partícula, atenuação da transmissão da luz, tipo, espessura e cor da resina composta, tempo de exposição, distância da fonte da luz e intensidade de luz.

A microdureza tem sido demonstrada como um fator indicador confiável para constatar o grau de conversão dos monômeros das resinas. O grau de polimerização é um indicador valioso do comportamento clínico das resinas compostas.

MONDELLII ${ }^{45}$ descreve, em 1998, uma técnica de confecção de núcleo intra-radicular utilizando um pino intra-radicular de cerâmica à base de zircônia, estabilizado com óxido de ítrio, onde este é cimentado com cimento adesivo e tem sua parte coronária reconstituída com resina composta. Posteriormente, sobre os dois dentes são instaladas coroas de porcelana pura In-Ceram. Nesse sistema os fabricantes preconizam a silanização do pino intra-radicular antes de reconstrução com resina. Ainda não pôde ser notado, pela exposição do caso clínico, efeito de férula no dente preparado. No mesmo texto, o autor utiliza um pino intra-radicular 
Flexi-Post aliado à resina composta para reconstruir a parte coronária de dentes anteriores, objetivando posterior instalação de coroas metalo-cerâmicas. Não foram empregados meios adicionais de retenção para o núcleo de preenchimento quando foi utilizado o pino de cerâmica.

ZALKIND; HOCHMAN ${ }^{69}$, em 1998, descrevem um método alternativo para a reconstrução coronária de dentes desvitalizados previamente à restauração definitiva. Ressaltam que se existe uma boa quantidade de estrutura dental remanescente e se um preparo conservador é feito no dente tratado endodonticamente, geralmente é possível instalar uma coroa sem um pino intraradicular. Nesse caso, a abertura do canal para tratamento pode ser preenchida com uma resina composta da cor do dente. Caso contrário, após o preparo do dente, se não existe estrutura suficiente, um pino intra-radicular cerâmico à base de zircônia pode ser colocado com uma resina composta. Neste caso, um pino intrarradicular cerâmico estabilizado por zircônia, pode ser usado com uma resina composta. As autoras ressaltam que o dente remanescente selecionado para essa técnica deve ter no mínimo a altura da futura coroa a ser instalada.

A técnica começa com o preparo do canal radicular para o pino, baseada nos princípios biomecânicos, utilizando-se uma série de brocas cilíndricas de acordo com as instruções do fabricante.

Segue com a seleção de um pino de acordo com o diâmetro e tamanho, estes obtidos através de radiografia.

O terceiro passo é o jateamento do pino cerâmico, como indicado pelo fabricante, e cimentação do mesmo.

O último passo é a completa reconstrução, com uma resina composta, da parte coronal do dente, e preparação que receba uma coroa de porcelana pura.

Ainda em 1998, ZALKIND; HOCHMAN ${ }^{68}$, preconizaram uma técnica de reconstrução coronal por via direta, utilizando como materiais o pino intraradicular de cerâmica à base de zircônia e resina composta onde, como meio de retenção da resina composta ao pino intra-radicular, confeccionaram ranhuras neste, 
além de jateamento com óxido de alumínio, promovendo uma macro-retenção mecânica para resina composta no pino intra-radicular à base de cerâmica de zircônia. As autoras argumentam que, desta maneira, a retenção destes é melhorada.

KAKEHASHI et al. ${ }^{34}$, descreveram, em 1998, os materiais e procedimentos de fabricação, tanto no consultório como no laboratório, de um novo sistema cerâmico para confecção de pinos intra-radiculares. Analisaram, in vitro, o efeito de condicionamento de superfície dos pinos intra-radiculares de cerâmica à base de zircônia com ácido hidrofluorídrico e posterior silanização e termociclagem.

Os autores descreveram duas técnicas de confecção de núcleos intra-radiculares, com a utilização de pino intra-radicular de cerâmica à base de zircônia e preenchimento coronário à base de cerâmica fundida.

A cerâmica escolhida foi a IPS Empress Post, constituída de $58,5 \%$ de $\mathrm{SiO}_{2}$ por peso, $15,5 \% \mathrm{ZrO}_{2} \%$ por peso, 4,0\% $\mathrm{P}_{2} \mathrm{O}_{5}$ por peso, e $8 \% \mathrm{Li}_{2} \mathrm{O}$ por peso, com 14 aditivos diferentes tais como $\mathrm{Na}_{2} \mathrm{O}, \mathrm{K}_{2} \mathrm{O}, \mathrm{Al}_{2} \mathrm{O}_{3}$ e Flúor. Nenhuma partícula feldspática foi adicionada para fundir essa cerâmica. A micro-estrutura da cerâmica após fundida não continha cristais de leucita. A parte cristalina consistiu

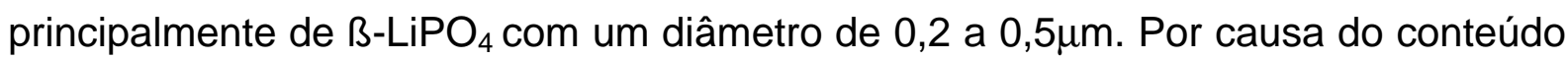
de $\mathrm{ZrO}_{2}$ em fase cristal, apareceram cristais de $\mathrm{Li}_{2} \mathrm{ZrSi}_{6} \mathrm{O}_{15}$. Uma técnica de fundição por cera perdida foi utilizada para prensar os lingotes de IPS Empress Post.

Para os procedimentos clínicos de ambas as técnicas, um pino intra-radicular de diâmetro adequado é escolhido e testado. Pode ser usada uma técnica direta ou indireta de confecção do pino intra-radicular. Para elementos unitários isolados, a técnica de confecção de um núcleo de preenchimento diretamente na boca é indicada, utilizando-se a técnica de Nealon; em seguida, utilizando-se a técnica da cera perdida, faz-se a fundição do preenchimento coronário. Esse é um processo semelhante ao processo tradicional, utilizado para confecção de núcleo metálico fundido.

A técnica indireta é usada quando se tem várias coroas unitárias que se queira reconstruir ao mesmo tempo. Os pinos intra-radiculares de zircônia são inseridos nas raízes e uma impressão de precisão é feita com os 
mesmos. Padrões de cera são esculpidos, utilizando-se os pinos intra-radiculares de cerâmica à base de zircônia como base. Os preenchimentos são incluídos e fundidos em cerâmica Empress Cosmo sem o pino intra-radicular. O preenchimento de Empress Post deve ser atacado em uma solução de ácido hidrofluorídrico a $2 \%$, em ultra-som, por aproximadamente $7 \mathrm{~min}$, para que melhor se adapte na parte intracanal. A superfície atacada é jateada com esferas de vidro sob pressão de 01 atm e as peças são limpas com vapor de água.

São feitas as provas dos pinos intra-radiculares por meio de controle radiográfico. A superfície interna da cerâmica de preenchimento é atacada com um gel contendo 4 a $5 \%$ de ácido fluorídrico. O núcleo de preenchimento é limpo em vapor de água ou ácido fosfórico e aplicado o silano. O núcleo de preenchimento cerâmico é cimentado ao mesmo tempo que o núcleo de preenchimento coronário, utilizando-se cimento dual ou com ativação química, juntamente com um sistema de agente de união.

Seguem-se os passos de confecção de uma coroa de porcelana pura convencional.

Nesse mesmo artigo, por um período de mais de 02 anos, os autores inseriram 24 pinos intra-radiculares com núcleo de preenchimento de IPS Empress Post 16 pacientes, sendo em 12 incisivos, 2 caninos e 10 pré-molares, num período de observação média de 15 meses, variando de 3 a 28 meses. Nenhuma falha foi observada até então.

A segunda parte do artigo determinou a influência do condicionamento na superfície do pino intra-radicular de zircônia e termociclagem na retenção dos núcleo de preenchimento de Empress.

Um grupo, chamado grupo experimental ( exp ), consistiu de pinos intra-radiculares cilíndricos de cerâmica à base de zircônia pré-fabricados, de $1,4 \mathrm{~mm}$ de diâmetro e $17 \mathrm{~mm}$ de comprimento. Um dispositivo de teflon foi utilizado para posicionar os pinos intra-radiculares no centro de um anel. Cera foi vertida no dispositivo formando um padrão aderido em volta dos pinos. Esses padrões foram fundidos com Empress Post. As dimensões finais dos núcleo de preenchimento cilíndricos foi de $1,4 \mathrm{~mm}$ de altura e $0,8 \mathrm{~mm}$ de diâmetro. Quatro grupos experimentais ( grupo 1 a 4 ) de 12 espécimes cada foram preparados. Antes da 
fundição do núcleo de preenchimento, os pinos intra-radiculares dos grupos 2 e 4 foram jateados com $\mathrm{Al}_{2} \mathrm{O}_{3}(50 \mu \mathrm{m})$. Antes de serem testados, todos os grupos foram armazenados em água a $37^{\circ} \mathrm{C}$ por um dia. Os grupos 3 e 4 foram subseqüentemente sujeitos à termociclagem ( $10.000 \mathrm{X})$, em água ( $\left.5^{\circ} / 55^{\circ} \mathrm{C}\right)$ por 333 horas.

Num outro grupo, chamado de referência ( ref ), utilizou-se o sistema de núcleos de preenchimento em forma de cilindros, cimentados aos pinos intra-radiculares de zircônia. Dois grupos de referência ( ref. 1 e 2 ) dos pinos intraradiculares/núcleo de preenchimento $(n=12)$ foram preparados. Cada cilindro, com $1,76 \mathrm{~mm}$ de diâmetro interno e $1,4 \mathrm{~mm}$ de altura, foi cimentado no pino intraradicular com cimento resinoso, usando-se o mesmo dispositivo de teflon para centralizar o pino intra-radicular no anel base. Os núcleos de preenchimento cimentados tinham a mesma dimensão que os núcleo de preenchimento fundidos. Os grupos de referência 1 e 2 receberam os mesmos tratamentos que os grupos experimentais 1 e 2, respectivamente. Cada corpo de prova de preenchimento foi assentado em uma base de teste específica, que foi posicionada numa máquina de teste. Os pinos foram forçados com um cilindro de aço a uma velocidade de 5 $\mathrm{mm} / \mathrm{min}$, até a separação.

Os resultados para as superfícies não tratadas dos pinos intra-radiculares mostraram que a técnica de porcelana fundida direta sobre o pino resultou em um significante aumento dos valores de retenção em relação à técnica de cimentação ( grupo exp 1 X grupo ref. 1 ). Para os pinos intra-radiculares jateados não existiu nenhuma diferença em retenção entre as duas técnicas ( $\exp 2 \mathrm{X}$ ref 2 ). Comparando o mesmo condicionamento de superfície dos pinos intra-radiculares ( $\exp 1 \mathrm{X} \exp 3$, e $\exp 2 \times \exp 4$ ), termociclagem severa ( $10000 X$ ), não tiveram nenhum efeito negativo significante na retenção dos núcleo de preenchimento cerâmicos. Após termociclagem, as superfícies dos pinos intra-radiculares jateados ( exp 4 ) mostraram uma retenção significantemente mais alta do que os pinos intraradiculares que não sofreram jateamento. Concluiu-se que antes de fundir porcelana Empress Post nos pinos pré-fabricados Cosmopost, dever-se-ía jateá-los com óxido de alumínio de micropartículas, para melhorar a adesão dos preenchimentos a eles. 
Em 1998, AKAGAWA et al. $^{2}$ realizaram um estudo em macacos para avaliar a biocompatibilidade e resistência de implantes à base de cerâmica parcialmente estabilizada por zircônia, cuja composição era de 94,2778\% de $\mathrm{Zr} ; 4,13 \%$ de Y; 1,58\% Hf; 0,0009\% Al; 0,0006\% Ca; 0,002\% Mg; 0,001\% Na; $0,002 \% \mathrm{Si} ; 0,007 \% \mathrm{Fe}$ e $0,0005 \%$ Ti. Os achados indicaram que os implantes parcialmente estabilizados por zircônia osseointegraram-se mantendo contato com o osso pelos 24 meses em que estiveram sob carga; quando analisados in situ todos os implantes estavam imóveis e a mucosa perimplantar sadia, demonstrando que esse material é biocompatível.

Já em 1999, LÜTHY; LOEFFEL; SCHÄRER ${ }^{42}$ testaram o jateamento da superfície, silanização e termociclagem dos pinos de cerâmica à base de zircônia. Dividiram seu estudo em 8 grupos, sendo que metade de cada um deles recebeu um tipo de tratamento diferente. Para cada pino foi confeccionado um preenchimento de porcelana vítrea com um diâmetro de $1,76 \mathrm{~mm}$ e altura de $1,4 \mathrm{~mm}$. Utilizando um dispositivo especial para garantir centralização, esses preenchimentos foram cimentados aos pinos com Panavia. Foram submetidos à tensão de cisalhamento a uma velocidade de $5 \mathrm{~mm} / \mathrm{min}$. Os grupos que usaram pinos jateados tiveram os melhores resutados ( 171 a $211 \mathrm{~N}$ ), enquanto que os grupos que utlizaram pinos não jateados obtiveram os piores resultados ( 25 a $48 \mathrm{~N}$ ). A termociclagem ( 3000x) e a silanização convencional não afetaram os valores de resitência.

Em 1999, SJÖGREN et al. $^{56}$ realizaram um estudo retrospectivo sobre o sucesso clínico de coroas de porcelana pura do tipo Empress ( Ivoclar ), em clínicas particulares na Califórnia. Foram consideradas coroas em dentes anteriores e posteriores; 37 coroas foram colocadas em incisivos, 06 em caninos, 25 em pré-molares e 42 em molares, sendo 14 em segundos molares. Doze coroas foram instaladas em dentes desvitalizados e as outras 98 foram colocadas em dentes considerados vitais. Os trabalhos foram feitos por 5 clínicos e utilizados 4 laboratórios dentais diferentes e as 110 coroas foram cimentadas com cimento resinoso. Totalizaram 29 pacientes, e o sistema de avaliação realizou-se de acordo com a Associação Dental da Califórnia. A avaliação foi feita após um período médio de instalação de 3,6 anos. A média de idade dos pacientes foi de 50,2 anos. Das 
coroas, $92 \%$ foram consideradas satisfatórias e $86 \%$ foram consideradas excelentes para integridade marginal. Foram registradas fraturas em $6 \%$ das 110 coroas. De acordo com o método de Kaplan e Meier, e o critério de fratura, o sucesso estimado após 5 anos seria de $91 \%$.

Preocupados com a sobrevida de restaurações intraradiculares a longo prazo, ISIDOR; BR $\varnothing N D U M ; R^{2} A N H O L T^{33}$ investigaram em 1999, a influência do tamanho do pino intra-radicular e o tamanho da férula, na resistência à ciclagem mecânica em dentes bovinos com pinos intra-radiculares préfabricados, de titânio.

Para tanto, usaram 90 dentes bovinos de tamanhos e dimensões similares.

As raízes foram divididas aleatoriamente em 09 grupos de 10 dentes. Os grupos foram preparados em diferentes combinações de tamanhos de pinos intra-radiculares ( de $5 ; 7.5$ e $10 \mathrm{~mm}$ ) e férulas ( de $0 ; 1.25$ e $2.5 \mathrm{~mm}$ ). Em todos os grupos, pinos intra-radiculares de titânio com sulcos paralelos e paredes paralelas de diâmetro de $1,75 \mathrm{~mm}$ da marca Parapost foram cimentados com cimento de fosfato de zinco. Parte do pino ( $2.5 \mathrm{~mm}$ ) foi deixada exposta na parte oclusal. A dentina foi tratada com sistema adesivo de acordo com as instruções do fabricante e os núcleos de preenchimento foram feitos com Concise.

A altura total dos núcleos de preenchimento com a férula foi de $5 \mathrm{~mm}$ para os dois grupos, e a convergência da superfície oposta do preparo foi de $15^{\circ}$. Coroas com altura de $9 \mathrm{~mm}$ foram enceradas fundidas em liga de ouro dura e cimentadas com cimento de fosfato de zinco. A superfície oclusal da coroas foi confeccionada num ângulo de 45 graus com o longo eixo do dente.

A retenção e estabilidade do complexo pino intraradicular/núcleo de preenchimento e/ou coroas foram testadas em testes de fadiga, com uma freqüência de 1 carga por segundo, com uma carga final de $400 \mathrm{~N}$. A direção da carga foi perpendicular à superfície oclusal das coroas. A máquina parava assim que o sistema falhava e registrava o número de ciclos ( fratura ou perda de coroa ou núcleo de preenchimento/pino intrarradicular). 
Quase todos os espécimes falharam por causa de fratura radicular, exceto para os 02 que tinham férula de $0 \mathrm{~mm}$, que perderam retenção do núcleo de preenchimento. Nos grupos com férula de $0 \mathrm{~mm}$ e um tamanho de pino intra-radicular de 5 ou $7.5 \mathrm{~mm}$ a falha ocorreu depois da primeira carga. Por outro lado, os dentes com férula de $2.5 \mathrm{~mm}$ e pino intra-radicular de $10 \mathrm{~mm}$ falharam por fratura radicular após 156,466 ciclos de carga. A diferença entre os grupos foi significativa. Assim, um aumento do tamanho da férula aumentou significativamente o número de ciclos de carga necessários à falha, enquanto o tamanho do pino intraradicular não influenciou no aumento esse número.

Foi concluído que para dentes com coroas com pino intraradicular/núcleo de preenchimento, um aumento no tamanho da férula é mais importante se quisermos adicionar resistência à carga cíclica, do que aumentar o tamanho do pino intra-radicular. No modelo usado, com tamanho de pinos intraradiculares médios ( $7.5 \mathrm{~mm}$ ), houve menor resistência a cargas cíclicas do que um pino intra-radicular menor ( $5 \mathrm{~mm}$ ) ou pino intra-radicular maior ( $10 \mathrm{~mm})$.

Em 1999, MORGANO; BRACKETT ${ }^{46}$ fizeram uma análise crítica da literatura disponível até este ano, como parte do Comitê de Pesquisa da Academia Americana de Prótese, considerando diversos aspectos. Dentre eles, os propósitos das restaurações que funcionariam como dentes pilares e seu papel para que o preparo desses pilares cumprissem adequadamente os requisitos de um pilar ideal. Advogaram a reconstrução dos dentes que serviriam como pilares, quando estes tivessem perdido metade ou toda a estrutura coronária.

Os autores sustentam que o espaço intra-radicular para colocação do pino deve oferecer resistência à rotação deste.

Destacam como desvantagem dos núcleos metálicos fundidos o fato de necessitarem duas visitas ao consultório.

Materiais restauradores devem suportar o estresse induzido por forças mastigatórias. Outros fatores tais como a quantidade de tecido dental residual, tempo de consulta clínica, facilidade de manipulação, devem ser considerados quando estamos selecionando o sistema de pinos intra- 
radiculares/núcleo de preenchimento. Considerações econômicas também podem afetar a escolha de uma técnica.

Os autores verificaram que o percentual de uso de pinos pré-fabricados tem se tornado muito popular entre os dentistas dos Estados Unidos. Constataram que $40 \%$ dos dentistas generalistas usam pinos pré-fabricados na maioria das vezes, e que os mais usados são os pinos pré-fabricados serrilhados. Ainda que o uso de pinos pré-fabricados aliado a uma reconstrução de núcleo de preenchimento é geralmente tido como um método restaurador de escolha para molares desvitalizados com perda excessiva de substância dental

Em 1999, GATEAU; SABEK; DAILEY ${ }^{28}$ investigaram in vitro o comportamento de três tipos de materiais de preenchimentos diferentes ( amálgama de prata, ionômero de vidro reforçado com prata e resina composta ) sob coroas artificias metálicas, durante mastigação simulada.

Todos eles foram suportados por pinos intra-radiculares préfabricados de titânio ( Tenax, Whaledent, New York, N.Y. ).

Foram utilizados dentes pré-fabricados, escolhendo como dente padrão o primeiro pré-molar superior. Foram tratados endodonticamente. Os pinos intra-radiculares foram situados no longo eixo dos dentes e, cimentados com cimento de ionômero de vidro. O tamanho dos pinos intra-radiculares foi selecionado para não interferir na altura da coroa que seria adaptada ao dente usado. Os materiais restauradores foram manipulados e inseridos nos dentes de acordo com as instruções dos fabricantes.

Foram selecionados 75 núcleos de preenchimento, sendo 25 de cada material. Coroas foram esculpidas, fundidas em liga de Ni-Cr-Mo, e cimentadas com cimento de ionômero de vidro. Para cada material foi usado um método aleatório, que selecionou 20 espécimes para o teste e 5 para controle.

Um pino em forma de cúspide de pré-molar antagonista foi aplicado sobre as fossas das coroas, num movimento para cima e para baixo, induzindo um movimento circular excêntrico. A média de tempo de contato com os dentes antagonistas durante movimentos oclusais foi de $522 \mathrm{~ms}$, a qual foi usada para ajustar o tempo de contato desejado entre os espécimes e os pinos de carga. Um total de 1,5 milhões de impactos mastigatórios foram programados, usando-se 
uma força de carga de $400 \mathrm{~N}$, que corresponde à força muscular desenvolvida durante atividade funcional e parafuncional. Os espécimes que suportaram essa quantidade de ciclos foi estimado terem suportado o equivalente a 4 anos de mastigação normal. Foram analisados com microscopia metalográfica ( 40X ), e a confirmação das observações foram obtidas subseqüentemente, por meio de um microscópio eletrônico de varredura.

As observações microscópicas evidenciaram fraturas iniciando-se nos pinos intra-radiculares, fraturas dentro do material, variação de separação ao longo dos pinos intra-radiculares, micro-infiltração cervical e presença de porosidade. Foram feitas, também, análises macroscópicas e observou-se que os corpos de prova de amálgama de prata não havia defeitos, enquanto que nos de resina composta os defeitos foram observados entre o núcleo de preenchimento e o pinos intra-radiculares. Nos espécimes de ionômero de vidro ocorreram tanto fraturas entre o ionômero e o pino intra-radicular, como no corpo do ionômero. Os autores concluíram que o amálgama de prata é muito mais resistente que a resina composta, sendo esta muito mais resistente que o lonômero de vidro.

$\mathrm{CHO}$ et al. ${ }^{16}$ testaram, em 1999, a resistência à compressão e resistência à tração diametral de seis deferentes materiais preconizados no mercado como núcleos de preenchimento.

Os autores utilizaram espécimes cilíndricos com $6 \mathrm{~mm}$ de altura e $4 \mathrm{~mm}$ de diâmetro dos materiais a serem testados. Vinte e quatro horas após serem manipulados, foram armazenados em água destilada a $37^{\circ} \mathrm{C}$, até serem testados.

As Resinas Compostas ( Prodigy - 250,3MPa ) e ( Herculite - $\pm 220 \mathrm{MPa}$ ) foram as que apresentaram melhores resultados, havendo diferenças estatisticamente significante entre elas. $O$ amálgama de prata com alto teor de Cobre ( Valiant PHD ) teve valor inferior a 200MPa. Embora houvesse diferença estatisticamente significante entre esse material e as duas resinas, não houve diferença entre este último e a resina autopolimerizável testada ( Core Paste), que chegou a 200MPa. 
Os valores de resistência à tração diametral mostraram que a Prodigy obteve 55,1MPa, similar ao amálgama de prata Valiant PHD e perto da Herculite, que chegou próximo de 51MPa. Não houve diferença estatisticamente significante entre esses três materiais, mas houve entre eles e a resina autopolimerizável Core Paste, sendo os primeiros superiores.

Os outros materiais testados foram a resina modificada por titânio ( Ti-core ), os cimentos de ionômeros de vidro ( Vitremer, Ketac fill ), o ionômero modificado por amálgama de prata ( Ketac Silver ) e um Poliuretano ( Structure ).

Em 1999, KYNOMOTO et al. ${ }^{37}$ compararam a diferença de concentração de estresse em cavidades $\mathrm{Cl}$ l, entre resina composta fotopolimerizável e resina composta autopolimerizável, e verificaram que o padrão de distribuição em análise fotoelástica era similar. A concentração de estresse ocorria sempre nas linhas dos ângulos internos, em ambos tipos de resina. Os autores concluíram que a resina composta fotopolimerizável tem características de trabalho melhores que as da resina composta autopolimerizável, mas que o fator que mais contribui na magnitude do estresse interno nas restaurações não era a distribuição do estresse, mas sim a velocidade de polimerização. Sugerem ainda que o desenvolvimento de técnicas ou materiais que reduzam a velocidade de polimerização das resinas compostas, sem perda de suas propriedades mecânicas, levarão a uma redução do estresse interno dessas restaurações.

Finalmente, no ano 2000, SMITH; SCHUMAN; WASSON ${ }^{57}$ fizeram uma revisão sobre o uso dos pinos intra-radiculares e núcleos de preenchimento na odontologia atual. Apresentaram critérios biomédicos, baseados na literatura protética e guias restauradores para avaliarem os componentes básicos de quaisquer sistemas de núcleo de preenchimento e pinos intra-radiculares préfabricados.

Os núcleos metálicos fundidos estão indicados em dentes com canais elípticos ou excessivamente desgastados, enquanto os pinos préfabricados funcionam melhor em dentes com canais circulares pequenos. Os 
núcleos metálicos fundidos são geralmente mais conservadores quanto ao desgaste na estrutura remanescente dos dentes. No entanto, os pinos pré-fabricados requerem menos consultas e são de procedimentos menos complexos. Os pinos pré-fabricados são os mais utilizados atualmente nos Estados Unidos.

A seleção de um material dental deve basear-se em: ( 1 ) biocompatibilidade, ( 2 )propriedades físicas, ( 3 ) características de manipulação, ( 4 ) estética, e ( 5 ) economia.

O objetivo primário de qualquer pino intra-radicular é promover retenção para o núcleo de preenchimento. Pinos que são retidos primariamente por roscas, que são mecanicamente engajadas na dentina são considerados ativos, enquanto aqueles que não contatam a parede do canal, ou seja, suportam-se no cimento para retenção, são considerados passivos. Os pinos intra-radiculares ativos são mais retentivos que os passivos, e os de paredes paralelas serrilhados são mais retentivos que os cônicos. Mencionam que os pinos intra-radiculares convencionais são fabricados em aço inoxidável, titânio e ligas de titânio, ligas de ouro-platina-paládio, e aquelas que contêm cromo e bronze. Recentemente foram lançados no mercado os pinos de fibras de carbono.

A dureza e a corrosão são consideradas de maior relevância na seleção do metal do pino intra-radicular. $O$ titânio e as ligas de titânio são os mais resistentes à corrosão. Todavia, a resistência do titânio é muito menor do que as ligas de cobalto-cromo-molibdênio e aço inoxidável. No entanto, bronze e aço inoxidável são pouco resistentes à corrosão.

Os autores não citaram, em sua revisão, o lançamento comercial dos pinos de cerâmica à base de zircônia.

Resumindo, os autores preconizam que o pino intra-radicular pré-fabricado ótimo é aquele que tem alta resistência mecânica, material resistente à corrosão, possua boas características retentivas e de distribuição de estresse e seja capaz de ser instalado com um risco mínimo, tanto referente à perfuração radicular quanto à perda de estrutura dental remanescente. Conseqüentemente, os critérios para escolha de um pino intra-radicular pré-fabricado são: ( 1 ) resistência mecânica, ( 2 ) resistência à corrosão e retenção, ( 4 ) distribuição de estresse, ( 5 ) segurança, ( 6 ) conservação da estrutura dental. 
Analisando os materiais de preenchimento, citaram que as resinas compostas, incluindo as reforçadas, têm adequada resistência mecânica, capacidade de adesão e rápida cura. No entanto, a tendência à micro-infiltração e a baixa estabilidade dimensional são desvantagens desse material. O bom material deve ter as seguintes características: ( 1 ) fácil de usar, ( 2 ) cura rápida, ( 3 ) resistência mecânica, ( 4 ) estabilidade dimensional, ( 5 ) não apresentar microinfiltração e ( 6 ) ter mecanismos de adesão. 
PROPOSIÇÃO 


\section{PROPOSIÇÃO}

O presente trabalho propôs comparar a resistência de união através de forças de cisalhamento, dos seguintes sistemas de núcleos intraradiculares:

1) Pino pré-fabricado de cerâmica à base de dióxido de zircônia ( Cosmopost ) e como porção coronária:

a)-Cerâmica vítrea fundida ( IPS Empress Post ).

b)-Resina composta fotopolimerizável ( Tetric Ceram ).

2) Pino pré-fabricado de titânio ( Tenax ) e resina composta fotopolimerizável ( Tetric Ceram ). 
MATERIAL E MÉTODOS 


\section{MATERIAL E MÉTODOS}

Foram utilizados 20 pinos de cerâmica à base de zircônia Cosmopost ( Ivoclar ) com $1,76 \mathrm{~mm}$ de diâmetro, $21 \mathrm{~mm}$ de comprimento, com paredes paralelas e terço apical cônico, jateados por micropartículas de óxido de

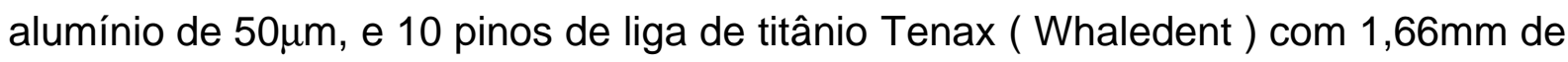
diâmetro, $17 \mathrm{~mm}$ de comprimento com paredes paralelas, serrilhado, com o terço apical cônico para confecção dos corpos de prova. ( Figura 4.1)

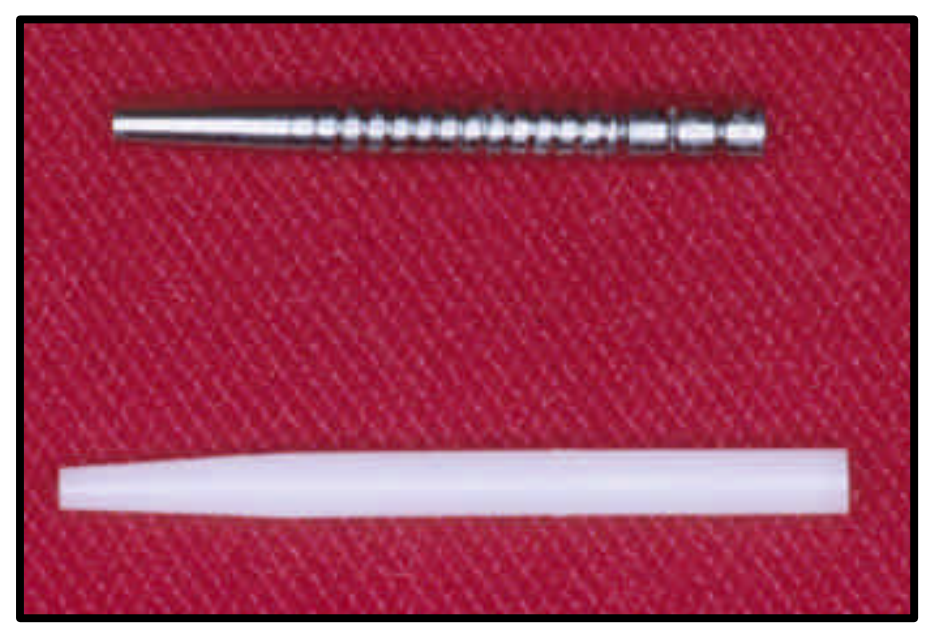

Figura 4.1 - Pinos de cerâmica à base de dióxido de zircônio e de titânio.

Uma cerâmica vítrea IPS Empress Post ( Ivoclar ) em lingotes, foi utilizada para formar a porção coronária dos corpos de prova. Foram obtidos 10 pinos em conjunto com cerâmica à base de zircônia.

Foi utilizada, com a mesma finalidade, uma resina composta híbrida Tetric Ceram ( Ivoclar), opaca, na cor A3,5 para confecção de 10 corpos de prova com 10 pinos de cerâmica à base de zircônia e com os 10 pinos de titânio.

Os corpos de prova foram divididos em três grupos:

- Grupo 1 - composto de 10 pinos de cerâmica e cerâmica vítrea.

- Grupo 2 - composto de 10 pinos de cerâmica e resina composta fotopolimerizável.

- Grupo 3 - composto de 10 pinos de titânio e resina composta fotopolimerizável. 
Todos os corpos de prova foram obtidos com a utilização de 02 matrizes de aço inoxidável formadas por duas partes,: uma matriz primária confeccionada com um cilindro com $39 \mathrm{~mm}$ de altura e $20 \mathrm{~mm}$ de diâmetro, com uma perfuração central com $1,8 \mathrm{~mm}$ de diâmetro seguindo seu longo eixo. A $12 \mathrm{~mm}$ da porção superior do cilindro foi feita uma perfuração transversa, onde um pino metálico era posicionado para suportar os pinos cerâmicos durante as fases de ceroplastia e inserção da resina, na confecção dos corpos de prova dos grupos $1 \mathrm{e}$ 2. A $11 \mathrm{~mm}$ da porção inferior da matriz foi confeccionada uma perfuração para que esta fosse estabilizada na máquina de testes.

Uma segunda matriz ( secundária ) com uma perfuração em seu centro de $6 \mathrm{~mm}$ de diâmetro, dividida em duas parte iguais era presa por quatro parafusos na matriz primária, para que pudesse ser removida, permitindo que os corpos de prova pudessem ser deslocados. ( Figura 4.2 )

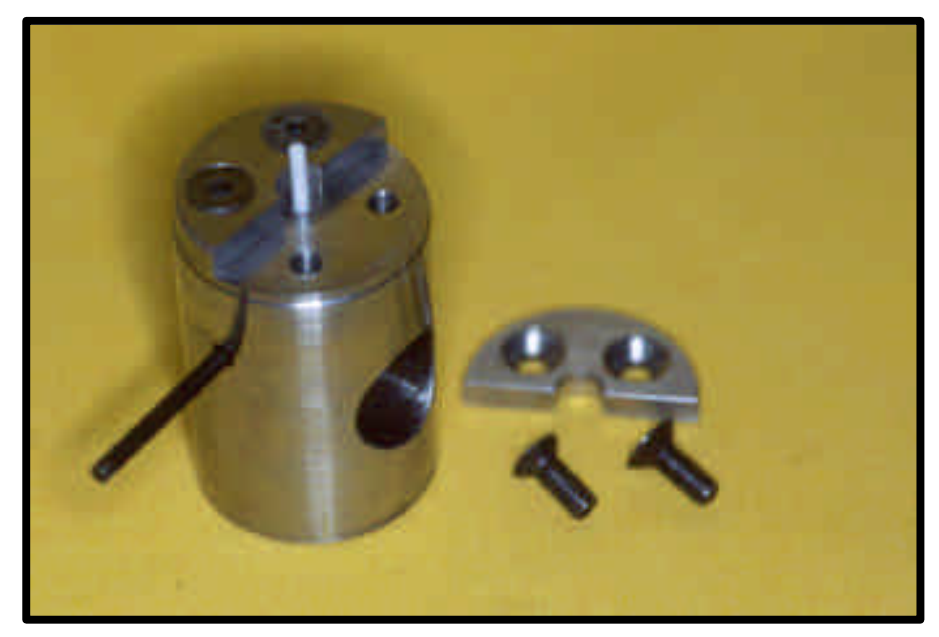

Figura 4.2 - Matrizes primária e secundária acopladas, para a confecção dos corpos de prova

Para a confecção dos corpos de prova com os pinos de titânio foi confeccionada uma outra matriz, alterando-se a perfuração central para $1,7 \mathrm{~mm}$, pois estes eram ligeiramente menores.

Todos os pinos, quando posicionados dentro das perfurações de sua respectivas matrizes, ficavam com $8 \mathrm{~mm}$ expostos acima da matrizes primárias e, após parafusada a matriz secundária, um remanescente de 
$4 \mathrm{~mm}$ permanecia exposto. O espaço de $4 \mathrm{~mm}$ contido dentro da matriz secundária era o espaço que seria aquele preenchido durante a ceroplastia e inserção da resina.

\subsection{Obtenção dos corpos de prova}

\subsubsection{Grupo 1 - pinos de cerâmica com preenchimento de cerâmica vítrea.}

Todos os espécimes deste grupo foram obtidos em temperatura ambiente, em torno de $23^{\circ} \mathrm{C}$, com uma variação de $\pm 2^{\circ} \mathrm{C}$, sob luz fluorescente. Os pinos de cerâmica à base de zircônia foram posicionados na perfuração longitudinal na matriz primária, de maneira que, com o posicionamento da matriz secundária, restou uma parte do pino de $4 \mathrm{~mm}$ exposta. Os pinos não receberam nenhum tipo de tratamento superficial, uma vez que o próprio fabricante não preconiza quaisquer tipos de tratamentos além daqueles feitos pelo fabricante. Uma vez posicionado cada pino, foi utilizado um instrumento de Peter Thomas $\mathrm{n}^{\circ}$ 2(Henry Schein-USA), para verter cera azul de dureza média ( Plastodent G - Degussa-Alemanha ) completando o espaço, até seu limite mais superior, e dado o acabamento da superfície com uma espátula 24 de aço ( Duflex ). ( Figura 4.3 )

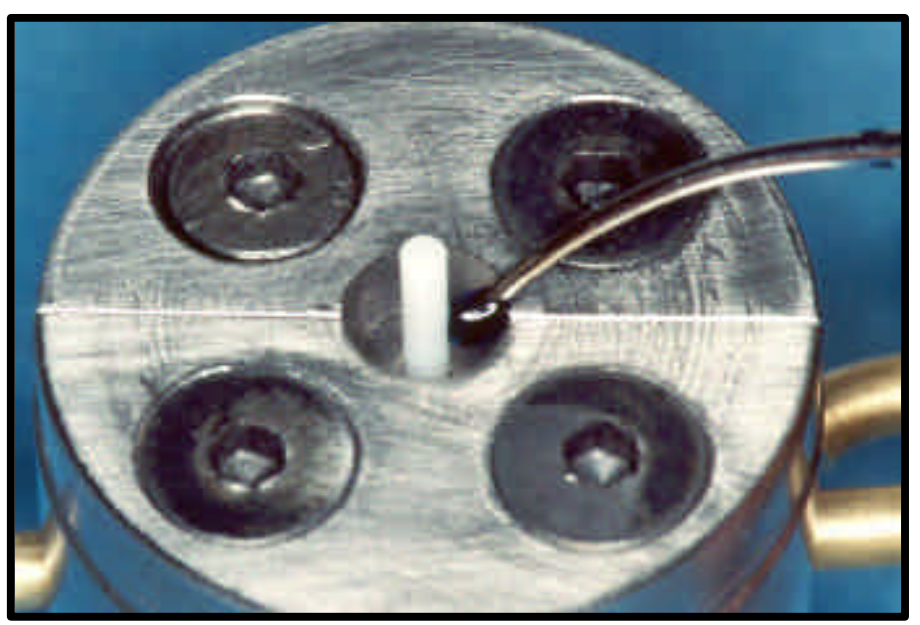

Figura 4.3 - Procedimento de ceroplastia. 
A matriz secundária foi removida e o conjunto Pino Cerâmica/Cera deslocado. Todos os corpos de prova do Grupo 1 foram assim obtidos. ( Figura 4.4 )

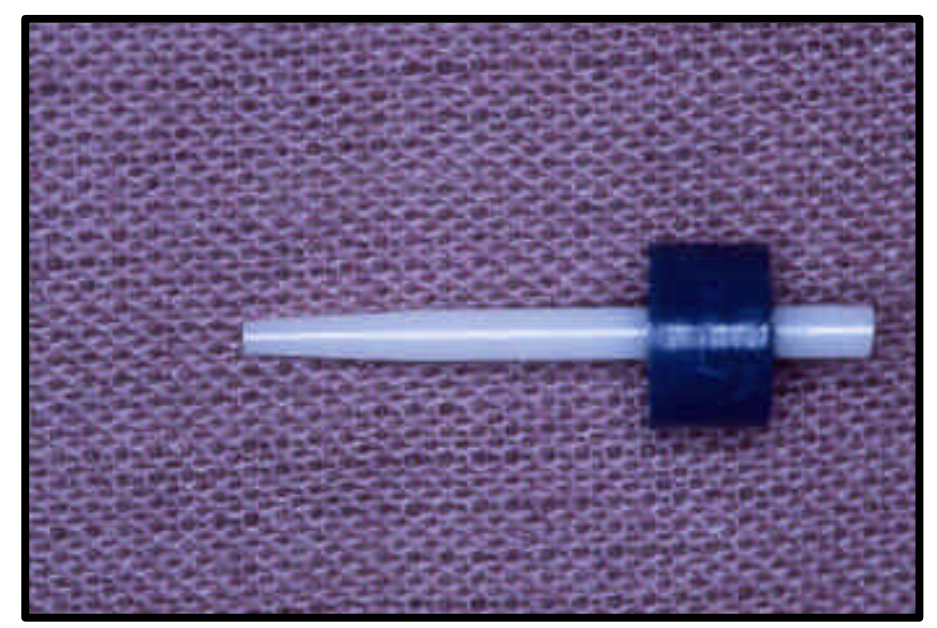

Figura 4.4 - Pino de cerâmica após a ceroplastia.

Após a obtenção dos corpos de prova em cera, os mesmos foram enviados a um laboratório especializado para fundição das porcelanas seguindo-se as instruções do fabricante.

Após a fundição, o anel foi deixado em temperatura ambiente até o completo resfriamento, desincluído e desgastado com pó de carborundum ( Dentorum ) até o revestimento ser diminuído consideravelmente; em seguida, foi jateado com esferas de vidro com granulação de $25 \mu \mathrm{m}$, a uma pressão que variava de 1 a 2 bar até sua limpeza completa. ( Figura 4.5 ) 


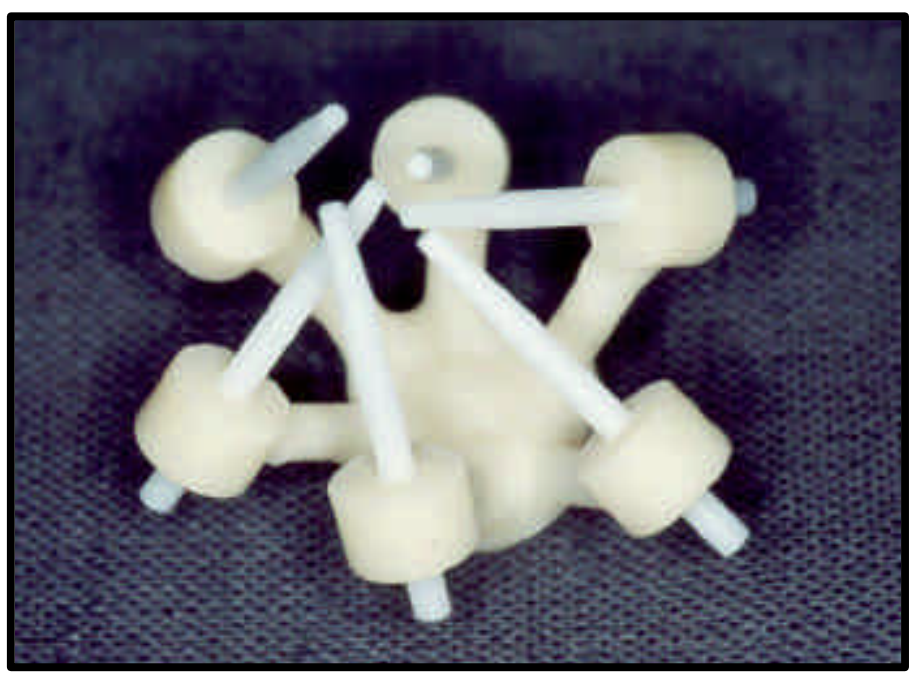

Figura 4.5 - Espécimes após a desinclusão.

Os corpos de prova foram separados com um disco de carborundum ( Dentorum). O excesso dos canais de alimentação foram desgastados com uma ponta montada ( Green Stone - Shofu ) até que adquirissem a forma circular original, e conferidas suas dimensões com paquímetro digital Mitutoyo.

A seguir, foram ajustados diretamente à matriz primária, utilizando um líquido de marcar Accufilm IV ( Parkell ), que foi aplicado na matriz. Os pontos de contatos foram desgastados com uma broca diamantada ( Ceramic) em baixa rotação até que um assentamento uniforme dos corpos de prova na matriz fosse conseguido.

\subsubsection{Grupo 2 - pinos de cerâmica à base de zircônia e preenchimento com resina composta fotopolimerizável.}

Todos os espécimes de resina foram obtidos em temperatura ambiente, em torno de $23^{\circ} \mathrm{C}$, com uma variação de $\pm 2^{\circ} \mathrm{C}$, sob luz fluorescente.

Para polimerização das resinas compostas, foi utilizada uma fonte de luz halógena, Optilux ( Demetron ), devidamente calibrada, com uma 
intensidade de luz de $400 \mathrm{~mW} / \mathrm{cm}^{2}$, que sempre era medida quando se iniciava a confecção de um novo espécime.

Previamente à confecção das restaurações, o aparelho de luz halógena foi aferido com um radiômetro Curing Radiometer Model 100 P/N 10503 Serial No 116095 ( Demetron ), que também foi aferido no Instituto de Física de São Carlos ( USP ) para verificação e calibração da intensidade da luz.

Os pinos de cerâmica à base de zircônia foram limpos com ácido fosfórico a 37\% ( Total Etch - Vivadent ) por 20 segundos e lavados com água destilada por 40 segundos. Em seguida foram secos com jatos de ar, e posicionados na perfuração longitudinal da matriz primária. A matriz secundária foi assentada sobre a primária, deixando uma porção exposta de pino de $4 \mathrm{~mm}$ (Figura 4.6). A inserção da resina composta Tetric Ceram dentro da matriz foi feita por meio de uma técnica incremental e polimerizada segundo YAMAUTI68.

Neste grupo, não foi necessário ajuste da resina composta à base de testes.

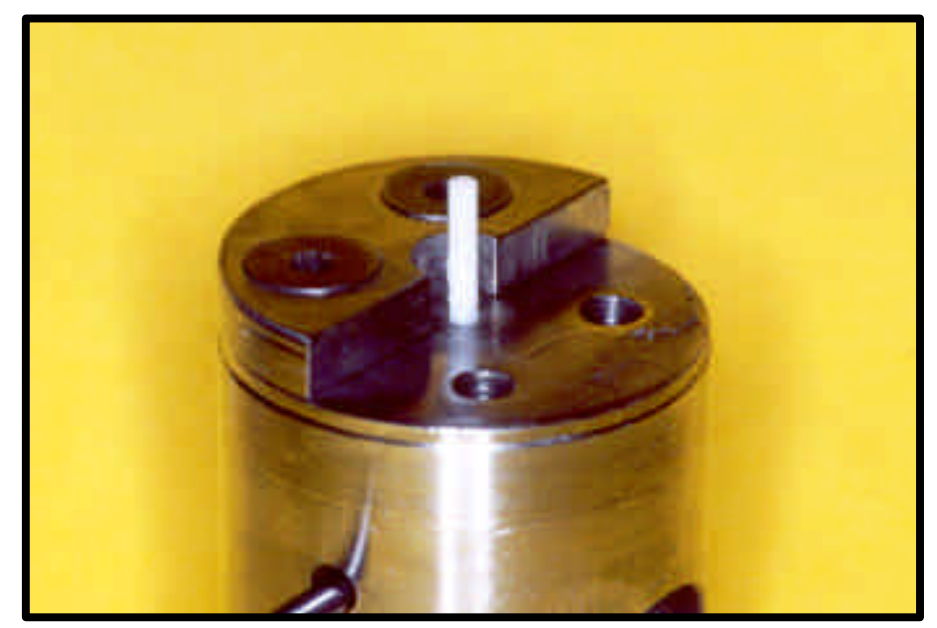

Figura 4.6 - Pino cerâmico posicionado para a inserção da resina composta.

\subsubsection{Grupo 3 - pinos de titânio com preenchimento de resina composta fotopolimerizável}

Neste grupo foi utilizada a matriz $n^{0} 2$ para confecção dos corpos de prova. Os pinos de titânio foram limpos com Cavidry ( DFL ), secos com 
jatos de ar, posicionados na matriz primária $n^{0} 2$ e a matriz secundária $n^{0} 2$ foi posicionada, permitindo uma sobra de $4 \mathrm{~mm}$ de pino além da superfície desta última.

O processo de inserção da resina composta para obtenção dos corpos de prova obedeceu as técnicas e critérios do grupo 2. ( Figura 4.7 )

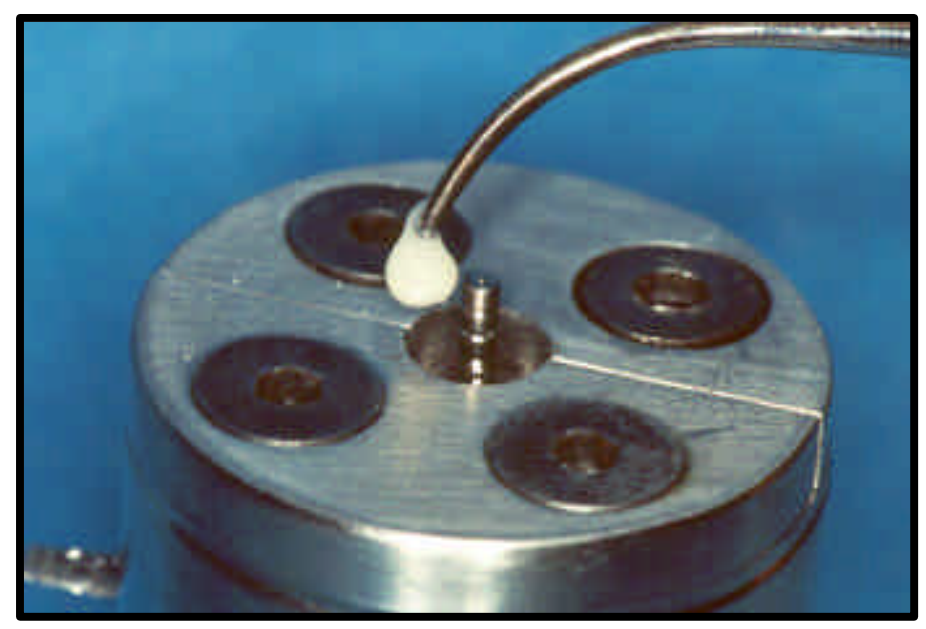

Figura 4.7 - Inserção da resina composta.

\subsection{Testes de cisalhamento}

Foi utilizada para todos os testes de cisalhamento uma Máquina Universal de Ensaios Kratos, modelo K-2000MP, com uma célula de $100 \mathrm{Kg}$ acoplada para os testes de todos os grupos. ( Figura 4.8 )

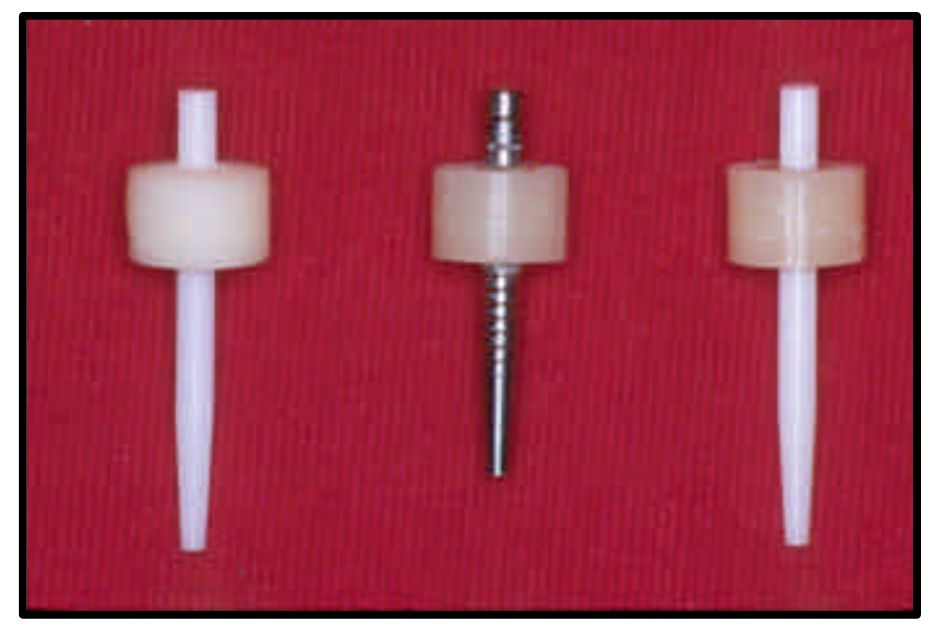

Figura 4.8 - Espécimes prontos para o ensaio. 
Para os corpos do grupo 1 foi instalada a matriz primária $n^{0} 1$ na máquina de testes Kratos ( Figura 4.9 ).

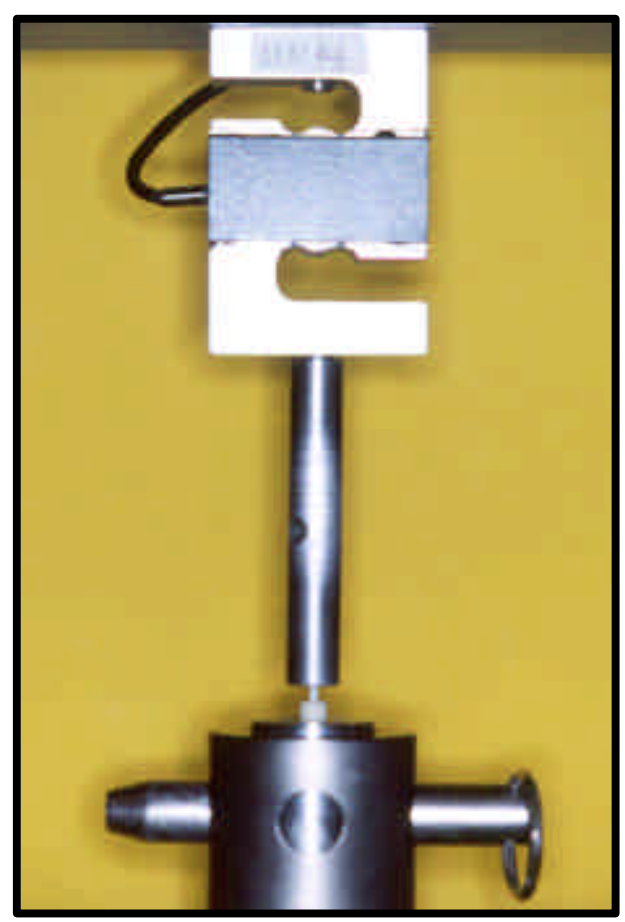

Figura 4.9 - Ensaio dos espécimes do grupo 1.

Um cilindro acoplado à célula de $100 \mathrm{Kg}$ da máquina de testes foi posto em contato com a superfície superior dos pinos assentados na base de prova. A máquina foi acionada a uma velocidade de $0,5 \mathrm{~cm} / \mathrm{min}$, até que um dos componentes do complexo pino/preenchimento ou a adesão entre eles falhasse. Os dados foram registrados em um computador com o programa Tração - Compressão Tracomp. Um gráfico da progressão da carga e comportamento de cada corpo de prova foi registrado.

Para grupo 2 foi feito o mesmo procedimento.

Para o grupo 3, a matriz primária $\mathrm{n}^{\circ} 2$ foi acoplada à máquina Kratos. Os corpos de prova desse grupo foram assentados nessa base e foram seguidos os mesmos procedimentos dos grupos 1 e 2 . 
DISCUSSÃO 


\section{DISCUSSÃO}

Um problema freqüente encontrado na clínica é o planejamento restaurador de um dente tratado endodonticamente. Os profissionais têm a sua disposição uma gama de materiais, que às vezes trazem dificuldades na indicação mais adequada para cada tratamento.

O presente estudo procurou esclarecer um dos fatores relativos à utilização de núcleos intra-radiculares: a adesão entre o material de preenchimento e o pino intra-radicular.

Quando duas substâncias são colocadas em contato íntimo entre si, as moléculas de um substrato aderem ou são atraídas pelas molécula de outro substrato. Esta força é denominada adesão quando moléculas dissimilares são atraídas, e coesão quando isto ocorre com moléculas similares. O material ou película adicionada para produzir a adesão é conhecido como adesivo, enquanto o material ao qual este é aplicado é denominado aderente. ${ }^{3}$

Por outro lado, quando duas substâncias são dispostas de maneira semelhante, uma forte aderência pode ser obtida por intermédio de união mecânica ou retenção, ao invés de atração molecular.

A união mecânica pode envolver mecanismos mais sutis, como a penetração de sistema fluido em irregularidades microscópicas ou submicroscópicas ( porosidades) na superfície do substrato ${ }^{3}$. Assim, uma união pode ser atribuída a dois fatores: efeitos geométricos e reológicos. $O$ efeito geométrico causado por rugosidades ou porosidades microscópicas de uma superfície, produz uma retenção por embricamento. O efeito reológico é um fator de união mecânica causado pelo escoamento do material na fase líquida em torno de uma projeção mecânica e passando, posteriormente, a um estado sólido, sofrendo uma contração. Essa adaptação por efeito contrátil é oriunda da contração de cura do material.

Um dos testes utilizados para avaliar este comportamento é o de cisalhamento, em que se considera a adesão entre duas estruturas colocadas em contato através de superfícies planas, onde uma força é incidida em um dos dois componentes. Esses testes ${ }^{9,54}$ são contraditórios, uma vez que se a força for 
feita em um dos componentes, apresenta um valor e, se feita no outro, o resultado pode ser diferente. ${ }^{48} \mathrm{~A}$ opção por um teste de cisalhamento como o realizado no presente trabalho condiz com a situação clínica, na qual um pino intra-radicular é totalmente circundado por um preenchimento.

Numa época inicial de confecção de núcleos intraradiculares, a preocupação se resumia apenas em prover retenção para as coroas. Os materiais utilizados nessa época, obtidos por fundição de ligas metálicas demonstram altas taxas de sucesso ao longo dos anos ${ }^{11,22}$. Com o desenvolvimento de novas técnicas e materiais, começaram a surgir novas alternativas para o tratamento de dentes tratados endodonticamente como por exemplo, os pinos intraradiculares pré-fabricados e materiais de preenchimento tal como as resinas compostas. Paralelamente, houve um aperfeiçoamento dos sistemas de porcelana pura, que apresentaram valores de resistência, cada vez mais elevados quando submetidos aos mais variados tipos de testes ${ }^{51,52,62}$, demonstrando muitas melhoras no âmbito clínico, com pequena quantidade de falhas por fraturas. ${ }^{26}$

Tudo isso aliado ao desenvolvimento de melhores materiais, fez crescer o interesse relacionado à estética por parte dos pacientes, exigindo cada vez mais dos profissionais e dos materiais dentários ${ }^{26,39,68,70}$.

MORGANO ${ }^{46}$ cita que os pinos pré-fabricados tem sido preferidos pela grande maioria dos profissionais norte-americanos, em detrimento do uso de núcleos metálicos fundidos.

FRADEANI; AQUILANO, ${ }^{26}$ relataram um acompanhamento de 3 anos de 144 coroas de porcelana pura. Dentre estas, 5 fracassaram, sendo que duas por falha do núcleo de preenchimento de resina composta. Nenhuma delas apresentou problemas relacionados aos núcleos intra-radiculares, quando feitos de amálgama ou ouro.

Diversos trabalhos tem sido realizados para testar os materiais de preenchimento através das mais diversas metodologias.

COHEN et al. ${ }^{18}$, por exemplo, testaram a resistência de vários conjuntos de pinos intra-radiculares e materiais de preenchimento, sempre tendo como material resinoso o Ti-Core, que é uma resina modificada por titânio, e obtiveram resultados entre 163 e $274 \mathrm{MPa}$. Estes resultados variaram de acordo com 
o ângulo de incidência das forças de compressão. Cabe notar que neste trabalho os pinos foram cimentados em dentes, e depois, realizado o preenchimento. A força era incidida sempre sobre o preenchimento até a falha de um dos componentes. Com esta metodologia, os autores testaram não somente o material de preenchimento, mas também a resistência do dente, do pino e do agente cimentante.

A grande maioria dos trabalhos revisados ${ }^{18,19,29,60}$ utilizam metodologias similares, ou seja, testam conjuntos com diversas variáveis incluídas. Desta maneira, não se consegue obter valores isolados de adesão entre pino e material de preenchimento.

Num trabalho recente, foi estudado a interface de diferentes sistemas de pinos intra-radiculares com resina composta submetidos à fadiga. Nos espécimes em que foram usados pinos de zircônia com preenchimento de resina compostas foram obtidos os índices mais altos de solução de contigüidade, ou seja, houve uma influência adversa na adaptação entre o conjunto núcleo de preenchimento/pino intra-radicular e a dentina. ${ }^{25}$

Este trabalho laboratorial confirma a teoria de que as resinas tem ótimas propriedades mecânicas, se consideradas a resistência à compressão e tração diametral. ${ }^{5,6,16}$ No entanto, seu baixo módulo de elasticidade é citado como uma característica negativa, uma vez que está aliado a sua diminuída adesão à dentina após fadiga ou mudanças microestruturais desta. Estes fatores impõem algumas restrições ao seu uso como núcleo de preenchimento, tais como a presença de remanescente dentinário coronário e uso em dentes restaurados isoladamente, ou no máximo, suporte para prótese parciais fixas de 03 elementos.

Tem sido sugerido que 0 efeito de férula aumenta significantemente a resistência dos dentes tratados endodonticamente à fratura, assim como a estabilidade da coroa instalada nesses dentes. . $^{8,33,60}$

Recentemente, foi introduzido um sistema que alia o uso de pinos cerâmicos com cerâmica vítrea fundida ou resinas compostas. A utilização desses pinos permitiria a instalação de coroas de porcelana pura garantindo 0 aproveitamento de suas melhores características óticas de transmissão de luz. ${ }^{34,53,62}$ 
As características de biocompatibilidade e resistência à corrosão, somadas às características mecânicas dessas cerâmicas as tem tornado excelentes materiais para confecção de núcleos intra-radiculares. ${ }^{17,27,34,53,62}$

O que se observa na literatura, no entanto, é que alguns autores não tem se preocupado com essas limitações, lembrando-se somente dos benefícios estéticos relacionados ao seu uso, negligenciando, às vezes, casos onde não ocorre o efeito de férula causado pelo abraçamento da coroa em torno do remanescente dental coronário.

Isso se agrava ao considerarmos a contração de polimerização, que gera um estresse mecânico na resina composta. Este fenômeno pode romper as ligações entre o sistema adesivo e estrutura dental. ${ }^{38,64}$

Um recurso altamente utilizado para controlar os efeitos da contração de polimerização é a técnica de inserção da resina composta na cavidade. Através de sua utilização, obtém-se uma diminuição da formação de fendas, mas não um completo selamento ${ }^{36,63,69}$

No presente trabalho, os mesmos cuidados foram tomados para minimizar estes efeitos pela técnica descrita nos materiais e métodos.

A escassa literatura e recente comercialização dos pinos de cerâmica à base de zircônia ${ }^{21}$ motivou a realização deste experimento “in vitro".

O grupo de pinos de titânio foi usado como comparação, pois o titânio é biocompatível, não sofre corrosão, é resistente às cargas mastigatórias e são relatados acompanhamentos a longo prazo $22,24,46$. A opção por pinos de paredes paralelas objetivou seguir a mesma forma dos pinos dos outros grupos, embora o tipo de união oferecida pelos pinos metálicos seja diferente das oferecidas pelos pinos de cerâmica. ${ }^{55,59,68,70}$

KAKEHASHI et al. ${ }^{34}$ utilizaram metodologia similar à empregada aqui para mensurar a adesão entre a cerâmica à base de zircônia e a cerâmica vítrea e, cerâmica à base de zircônia e resina composta. Algumas diferenças metodológicas foram observadas, tal como a dimensão dos preenchimentos (de $1,4 \mathrm{~mm}$ de altura por $0,8 \mathrm{~mm}$ de espessura ).

Os resultados destes autores, que podem ser comparados com os do presente trabalho, são os correspondentes aos grupos 3 , ( pinos 
jateados, com porcelana vítrea fundida ) e 4 ( pinos jateados, com porcelana vítrea cimentada), ambos sem termociclagem. Os resultados do grupo 1 mostrados na tabela 5.2 com média de 22,90MPa foram menores do que os do grupo 3 , com média de 38MPa encontrados no trabalho de KAKEHASHI et al. ${ }^{34}$ Isto poderia ser explicado pelas diferentes dimensões dos corpos de prova, os quais foram maiores no grupo aqui testado. Os processos laboratoriais de fundição, embora tenham sido realizados por uma equipe especializada, podem também não ter obedecido os mesmos padrões dos utilizados pelos autores, comprometendo a micro-estrutura da porcelana vítrea.

Ao compararmos os resultados do grupo 4, com média de $36,46 \mathrm{MPa}$ com os resultados do grupo 2, que obteve média de 12,66MPa mostrados na tabela 5.2 do presente trabalho, o primeiro foi quase $200 \%$ maior. Esta diferença poderia ser atribuída às resinas empregadas. Aqui, foi utilizada uma resina composta fotopolimerizável híbrida como preenchimento e no trabalho citado foi utilizado o cimento panavia autopolimerizável como agente cimentante entre o pino e os núcleos de porcelana fundida. Este material possui propriedades mecânicas inferiores às da resina aqui empregada, mas que indiscutivelmente promove um melhor molhamento das superfícies dos pinos, o que poderia resultar em melhor embricamento mecânico.

Em outro trabalho ${ }^{42}$, os autores compararam o efeito da silanização, do jateamento e da termociclagem na adesão da resina à cerâmica à base de zircônia. Neste trabalho, os grupos que nos interessaram foram aqueles em que se mensurou a resistência de adesão da resina aos pinos. Os resultados variaram de 28,21 a $34,81 \mathrm{MPa}$, muito altos, se comparados com os valores médios encontrados aqui ( $12,66 \mathrm{MPa})$, no grupo 2. Estas diferenças podem ser atribuídas , novamente às duas resinas utilizadas, sendo que no trabalho de LÜTHY; LOEFFEL;SCHÄRER ${ }^{42}$ foi utilizado o cimento panavia como agente cimentante entre os pinos de cerâmica à base de zircônia e os preenchimentos de cerâmica vítrea

Estes trabalhos ${ }^{34,42}$ testaram a silanização como processo para melhorar a adesão da cerâmica à base de zircônia com o cimento panavia, no entanto, não encontraram diferenças significantes com sua utilização. 
Provavelmente por esta razão, o fabricante dos pinos não recomenda sua utilização, princípio que também foi respeitado em nosso trabalho.

Apesar da tabela 5.2 mostrar um desvio padrão para o grupo 1 ( $0,22 \mathrm{MPa})$ muito pequeno, se comparado ao grupo $2(1,86 \mathrm{MPa})$ e o grupo 3 ( $1,42 \mathrm{MPa}$ ) todos os procedimentos foram igualmente padronizados. Ainda que não sejam similares aos dos trabalhos citados ${ }^{34,42}$ anteriormente, os valores de adesão aqui encontrados podem ser considerados de boa magnitude na odontologia.

Neste trabalho, os corpos de prova do grupo 2 foram os que apresentaram os menores valores, como apresentado nas tabelas 5.1 e 5.2 ( média $=12,66 \mathrm{MPa})$. Observa-se também um desvio padrão maior no grupo 2 $(1,86 \mathrm{MPa})$ do que aqueles dos grupos $1(0,22 \mathrm{MPa})$ e $3(1,42 \mathrm{MPa})$.

Como mostrado na tabela 5.4 , não houve diferença estatisticamente significante entre os grupos 1 e 3 , no entanto verificou-se uma diferença estatisticamente significante entre o grupo 2 e os grupos 1 e 3 .

A média dos valores do grupo 1 foi $80,90 \%$ maior do que a do grupo 2 e 2,4\% menor do que a do grupo 3 . A média de valores do grupo 3 foi $85,3 \%$ maior do que a do grupo 2 .

Além da adesividade obtida no grupo 1 ocorrer pela condição reológica da cerâmica vítrea fundida em contato com as rugosidades superficiais produzidas nos pinos pelo jateamento, deve-se também considerar que esta porcelana e os pinos são compostos por materiais cerâmicos semelhantes, ambos contendo zircônio. Isto deve possibilitar uma interação química entre ambos, condição esta que pode justificar os altos valores de adesão, haja vista que as fraturas observadas neste grupo tiveram sempre um componente adesivo e um coesivo.

Esta hipótese é corroborada por SORENSEN; MITO ${ }^{62}$ quando afirmam que os teste realizados por KAKEHASHI et al. ${ }^{34}$ demonstraram adesão elevada e confiável entre a cerâmica à base de zircônia e porcelana vítrea. Sugeriram que a adesão entre a porcelana vítrea e a cerâmica à base de zircônia se dá devido a um coeficiente de expansão térmica ligeiramente mais baixo da cerâmica vítrea comparado com o da cerâmica à base de zircônia; assim, atinge uma adesão sem estresse e sem trincas entre esses dois materiais. 
Por outro lado, a união conseguida pelas resinas compostas nas rugosidades superficiais dos pinos cerâmicos restringe-se somente ao efeito reológico, não exibindo ligações químicas, que aumentariam esta resistência. Devese considerar também que a resistência estrutural da resina composta é menor do que a da cerâmica vítrea. Isto é reforçado pelo padrão de fratura deste grupo, que foi adesivo.

Observou-se também que os sulcos confeccionados nos pinos de titânio são suficientes para garantir um embricamento mecânico que gera forças em torno de 23,45MPa, similares às encontradas no grupo 1. Neste caso, os valores foram tão grandes quanto a resistência estrutural das resinas compostas, 0 que pôde ser observado pelo tipo de fratura, coesiva, que ocorreu nos ensaios deste grupo.

Desde a década de 70, já pode se perceber na literatura, ${ }^{6,7,61}$ uma preocupação com a adesão entre os pinos pré-fabricados e a resina composta. Alguns autores preconizam o uso de pinos dentinários ${ }^{45} \operatorname{com}_{0}$ intuito de melhorar a retenção e estabilidade entre a resina composta e o remanescente dental. No entanto, quando se opta pelo uso de coroas de porcelana pura, este procedimento não é corriqueiro, uma vez que o preparo dental para esta técnica exige um grande espaço para obtenção das melhores características óticas das coroas de porcelana pura. ${ }^{47}$

O artifício retentivo que os pinos de zircônia oferecem para reter as resinas compostas é o jateamento com micropartículas. Diversos autores $^{1,34,42,53,62}$ sustentam que esse procedimento aumenta a resistência adesiva entre a resina composta e o pino de zircônia. A confecção de retenções mecânicas em forma de sulcos demonstrou mudar substancialmente as propriedades dos pinos de zircônia, sendo por isso não preconizado pelos fabricantes do pino usado neste estudo.

A metodologia utilizada para o teste do presente estudo não tem referências, quando se considera a adesão entre os pinos de titânio, zircônia e resina composta. Os valores de adesão apresentados pelos grupos 2 e 3 são laboratoriais, não significando no entanto, o mesmo comportamento clínico. Hipoteticamente, pode-se esperar comportamentos clínicos semelhantes destes 
esses dois grupos pois, o fracasso da adesão à estrutura dentinária faz toda a estabilidade do conjunto pino intra-radicular/resina composta recair na adesão entre si.

Os resultados obtidos e discutidos neste trabalho permitem concluir que os pinos de titânio com preenchimento de resina composta fotopolimerizável e pinos de cerâmica à base de zircônia se comportaram de maneira semelhante, seguidos pelos pinos de zircônia e resina composta. Embora estes resultados indiquem um melhor comportamento para os grupos 1 e 3, não podemos descartar a indicação de procedimentos clínicos para o grupo 2 .

Avaliações clínicas de longo prazo são importantes para afirmarmos melhor o comportamento destes pinos, permitindo uma análise mais criteriosa, pois comparações entre períodos de tempo maiores tornam-se mais consistentes e adequadas para afirmações mais concretas de sua utilização clínica. 
RESULTADOS 


\section{Resultados}

Podemos observar na Tabela 5.1 os valores individuais e médias dos testes de cisalhamento nos 3 grupos testados ( MPa ).

TABELA 5.1 - Valores obtidos para os testes de resistência ao cisalhamento com os corpos de prova dos três diferentes grupos testados ( MPa ).

\begin{tabular}{c|c|c|c}
\hline Amostra & Grupo 1 & Grupo 2 & Grupo 3 \\
\hline 01 & 23,01 & 13,27 & 20,31 \\
\hline 02 & 23,01 & 9,39 & 24,12 \\
\hline 03 & 23,03 & 14,25 & 24,12 \\
\hline 04 & 22,32 & 12,94 & 24,10 \\
\hline 05 & 23,01 & 11,83 & 21,24 \\
\hline 06 & 23,03 & 12,85 & 24,10 \\
\hline 07 & 23,03 & 14,52 & 24,12 \\
\hline 08 & 23,03 & 15,45 & 24,14 \\
\hline 09 & 22,76 & 11,59 & 24,14 \\
\hline 10 & 22,83 & 10,53 & 24,14 \\
\hline Média & 22,90 & 12,66 & 23,45 \\
\hline
\end{tabular}

Os resultados apresentados na tabela 2 mostram os valores das médias e desvios padrão das resistências ao cisalhamento dos grupos estudados ( MPa). 
TABELA 5.2 - Médias de valores de resistência ao cisalhamento dos 3 grupos testados ( MPa ).

\begin{tabular}{c|c|c|c}
\hline Grupos & Médias (MPa) & $\mathbf{n}$ & $\mathbf{D p}$ \\
\hline Grupo 1 & 22,90 & 10 & 0,22 \\
\hline Grupo 2 & 12,66 & 10 & 1,86 \\
\hline Grupo 3 & 23,45 & 10 & 1,42 \\
\hline
\end{tabular}

Os dados da Tabela 5.1 foram submetidos à análise de variância a um critério para avaliar a possibilidade de diferenças estatisticamente significantes entre as condições testadas ( Tabela 5.3 ).

TABELA 5.3 - Dados do teste estatístico de análise de variância a um critério obtidos dos ensaios de cisalhamento.

\begin{tabular}{c|c|c|c|c}
\hline EFEITO & $\begin{array}{c}\text { Graus de liberdade } \\
\text { do efeito }\end{array}$ & $\begin{array}{c}\text { Soma dos } \\
\text { quadrados }\end{array}$ & $\mathbf{F}$ & $\mathbf{P}$ \\
\hline $\begin{array}{c}\text { Entre } \\
\text { Grupos }\end{array}$ & 2 & 739.229 & 198,475 & $<0,001$ \\
\hline
\end{tabular}

A análise de variância mostrou haver diferença estatisticamente significante entre os grupos testados. Para fazer as comparações múltiplas entre os grupos analisados, os dados foram submetidos ao Teste de Tukey ( Tabela 5.4 ). 
TABELA 5.4 - Teste de Tukey para comparações múltiplas entre os grupos testados.

\begin{tabular}{c|c|c|c}
\hline $\begin{array}{c}\text { Combinação dos } \\
\text { materiais }\end{array}$ & Grupo 1 & Grupo 2 & Grupo 3 \\
\hline Grupo 1 & $<0,001^{*}$ & $0,714(\mathrm{~ns})$ \\
\hline Grupo 2 & $0,714(\mathrm{~ns})$ & $<0,001^{*}$ & $<0,001^{*}$ \\
\hline Grupo 3 & & & \\
\hline
\end{tabular}

* - diferença estatisticamente significante $(p<0,001)$.

(ns ) - diferença estatisticamente não significante.

Para uma melhor visualização dos resultados, foi confeccionado um gráfico com médias dos grupos, demonstrando as resistências dos diferentes grupos às cargas impostas em MPa ( Figura 5.1 ).

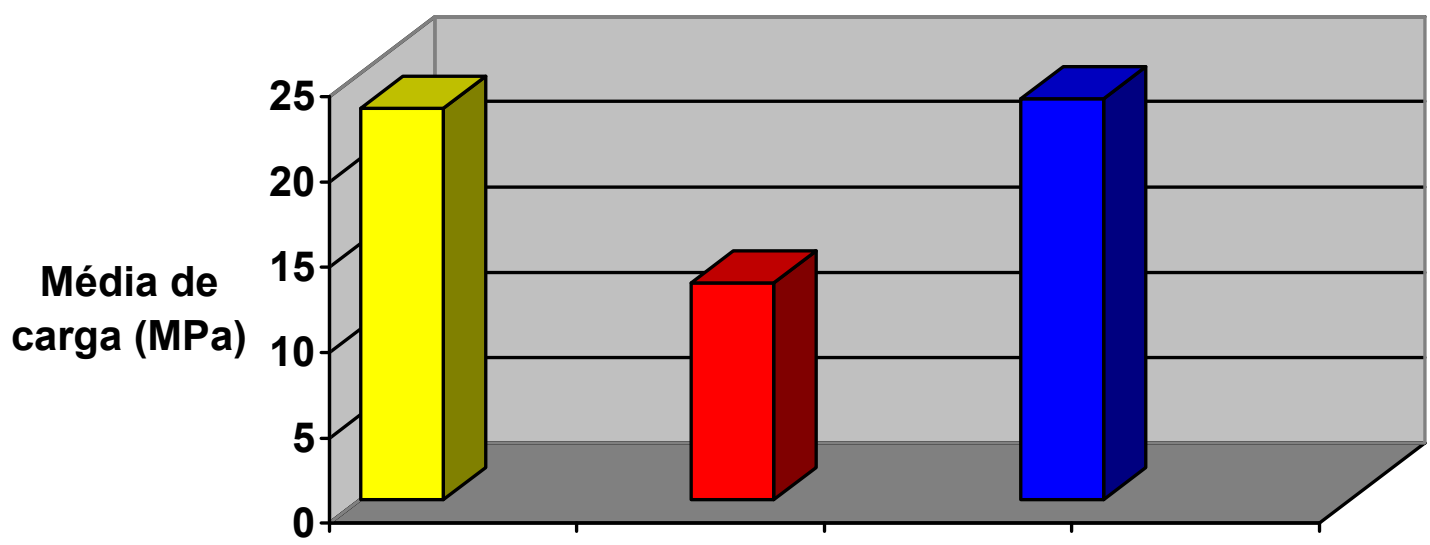

$\square$ Zirc. X Emp. $\square$ Zirc. X Res. Comp. $\square$ Tit. X Res. Comp.

FIGURA 5.1 - Gráfico ilustrativo dos valores de carga suportados até a fratura para os três grupos estudados, expressos em MPa. 
CONCLUSÃO 


\section{CONCLUSÃo}

De acordo com a proposição inicial, dentro das condições em que foi desenvolvido o experimento e em função da análise estatística dos resultados obtidos, entendemos poder-se elaborar as seguintes conclusões:

I. O grupo em que foram utilizados pinos de titânio com preenchimento de resina composta foi o que apresentou maiores valores numéricos de adesão dentre os grupos estudados.

II. O grupo em que foram utilizados pinos de zircônia com preenchimento de resina apresentou os menores valores de adesão dentre os grupos estudados.

III. Os grupos 1 - Pinos de Zircônia X Porcelana vítrea IPS Empress Post - e 3 - Pinos de Titânio X Resina Composta - não apresentaram diferenças estatisticamente significantes entre si, mas ambos apresentaram quando comparados ao grupo 2 . 
REFERÊNCIAS BIBLIOGRÁFICAS 


\section{REFERÊNCIAS BIBLIOGRÁFICAS *}

1- AHMAD, I. Yttrium-partially stabilized zirconium dioxide posts: an approach to restoring coronally compromised nonvital teeth. Int. J. Periodont. Restorat. Dent., v.18, n.5, p.455-66, Oct. 1998.

2- AKAGAWA, Y. et al. Comparison between freestanding and tooth-connected partially stabilized zirconia implants after two years' function in monkeys: a clinical and histologic study. J. prosth. Dent., v.80, n.5, p.551-8, Nov. 1998.

3- ANUSAVICE, K.J. Phillips materiais dentários. 10. ed. Rio de Janeiro, Guanabara Koogan, 1998.

4- ATMADJA, G.; BRYANT, R.W. Some factors influencing the depth of cure of visible light-activated composite resins. Aust. dent. J., v.35, n.3, p.213-8, June 1990.

5- BAHARAV, $\mathrm{H}$. et al. Effect of. irradiation time on tensile properties of stiffness and strength of composites. J. prosth. Dent., v.77, n.5 , p.471-4, May 1997.

6- BARABAN, D.J. Immediate restoration of pulpless teeth. J. prosth. Dent., v.28, n.6, p.607-12, Dec. 1972.

7- BARABAN, D.J. The restoration of endodontically treated teeth: an update. J. prosth. Dent., v.59, n.5, p.553-62, May 1988.

\footnotetext{
* Normas recomendadas para o uso no âmbito da Universidade de São Paulo, com base no documento "Referências Bibliográficas: exemplos", emanado do Conselho Supervisor do Sistema Integrado de Bibliotecas da USP em reunião de 20 de Setembro de 1990.
} 
8- BARKHORDAR, R.A.; RADKE, R.; ABBASI, J. Effect of metal collars on resistence of endodotically treated teeth to root fracture. J. prosth. Dent., v.61, n.6, p.676-8, June 1989.

9- BATISTA, J.G. Avaliação da resistência de união metalocerâmica utilizando os sistemas opacos em pasta, convencional e agente de união. Ribeirão Preto, 1997. 120p. Dissertação (Mestrado) - Faculdade de Odontologia de Ribeirão Preto, Universidade de São Paulo.

10- BENNETT, B. et al. Ligth source distance and temperature effects on composite polymerization. J. dent. Res., v.73, p.227, 1994. Special issue /Abstract n. /1002/

11-BERGMAN, B. et al. Restorative and endodontic results after treatment with cast post and cores. J. prosth. Dent., v.61, n.1, p.10-5, Jan. 1989.

12- BRYANT, R.W.; MAHLER, D.B. Modulus of. elasticity in bending of composites and amalgms. J. prosth. Dent., v.56, n.2, p.243-8, Aug. 1986.

13-BURGESS, J.O. et al. Directly placed esthetic restorative materials - the continuum. Comp. Cont. Educ. Dent., v.17, n.8, p.731-47, Aug. 1996.

14- CALES, B.; STEFANI, Y.; LILLEY, E. Long-term in vivo and in vitro aging of a zircônia ceramic used in orthopaedy. J. Biom. Mat. Res., v.28, n.5, p.61924, May 1994.

15- CARVALHO, R.M. et al. A review of polimerization contraction: the influence of stress development versus stress relief. Oper. Dent., v. 21, n.1, p.17-24, Jan. 1996. 
16- $\mathrm{CHO}$, G.C. et al. Diametral and compressive strength of dental core materials. J. prosth Dent., v.82, n.3, p.272-6, Sept. 1999.

17- CHRISTEL, P. et al. Mechanical properties and short-term in-vivo evaluation of yttrium-oxide-partially-stabilized zirconia. J. Biomed. Mat. Res., v.23, p.4561, Jan. 1989.

18- COHEN, B.I. et al. Four different core materials measured for fracture strength in combination with five different designs of endodontic posts. J. prosth. Dent., v.76, n.5, p.487-95, Nov. 1996.

19- COHEN, B.I. et al. Cyclic fatigue of five endodontic post designs supportes by four core materials. J. prosth. Dent., v.78, n.5, p.458-64, Nov. 1997.

20- COHEN, B.I. et al. Fracture strength of three core restorative materials supported with or without a prefabricated split-shank post. J. prosth. Dent., v.78, n.6, p.560-5, Dec. 1997.

21- COSMOPOST E IPS EMPRESS PASTILLAS COSMO. Perfil Técnico. Austria Ivoclar, 1997.

22- CREUGERS, N.H.J.; MENTINK, A.G.B.; KAYSER, A.F. An analysis of durability data on post and core restorations. J. Dent., v.21, n.5, p.281-4, Oct. 1993.

23- DAVIDSON, C.L.; FEILZER, A.J. Polymerization shrinkage and polymerization shrinkage stress in polymer-based restoratives. J. Dent., v.25, n.6, p.435-40, Nov. 1997.

24- DEUTSCH, A.S. et al. Prefabricted dowels: a literature review. J. prosth Dent., v.49, n.4, p.498-503, Apr. 1983. 
25- DIETSCHI, D.; ROMELLI, M.; GORETTI, A. Adaptation of adhesive posts and cores to dentin after fatigue testing. Int. J. Prosth, v.10, n.6, p.498-507, Nov. 1997.

26- FRADEANI, M.; AQUILANO, A. Clinical experience with empress crowns. Int. J. Prosth., v.10, n.3, p.241-7, May 1997.

27- GARVIE, R.C.; HANNINK, R.H.; PASCOE, R.T. Ceramic steel? Nature, v.258-9, n.25, p.703-4, Dec. 1975.

28- GATEAU, P.; SABEK, M.; DAILEY, B. Fatigue testing and microscopic evaluation of post and core restoration under artificial crowns J. prosth. Dent., v.82, n.3, p.341-7, Sept. 1999.

29- GUZY, G.E.; NICHOLLS, J.I. In vitro comparison of intact endodontically treated teeth with and without endo-post reinforcement. J. prosth. Dent., v.42, n.1, p.39-44, July 1979.

30- HEALEY, H.J. Restoration of the effectively treated pulpless tooth. J. prosth. Dent., v.4, n.6, p.842-9, Nov. 1954.

31- HOLMES, D.C.; DIAZ-ARNOLD, A.M.; LEARY, J.M. Influence of post dimension on stress distribution in dentin. J. prosth. Dent., v.76, n.2, p.140-7, Fev. 1996.

32- HUYSMANS, M-C.A.D.N.J.M.; VARST, P.G.T. Mechanical longevity estimation model for post-and-core restorations. Dent. Mat., v.11, n.4, p.252-7, July 1995.

33- ISIDOR, F.; BRØNDUM, K.; RAVNHOLT, G. The influence of post length and crown ferrule length on the resistance to cyclic loading of bovine teeth with prefabricated titanium posts. Int. J. Prosth., v.12, n.1, p.78-82, Jan. 1999. 
34-KAKEHASHI,Y. et al. A new all-ceramic post and core system: clinical, technical and in vitro results. Int. J. Periodont. Restorat. dent., v.18, n.6, p.587-94, Dec. 1998.

35- KELLY, J.R.; NISHIMURA, I.; CAMPBELL .S.D. Ceramics in dentistry: historical roots and current perpectives. J. prosth. Dent., v.75, n.1, p.18-32, Jan. 1996.

36-KEMP-SCHOLTE, C.M.; DAVIDSON, C.L. Marginal sealing of curing contraction gaps in class $\mathrm{V}$ composite resin restorations. J. dent. Res., v.67, n.5, p. 841-5, May 1988.

37-KINOMOTO, Y. et al. Comparison of polimerization contraction stresses between self- and light-curing composites. J. Dent., v.27, n.5, p.383-90, July 1999.

38-KORAN, P.; KURSCHNER, R. Effect of sequential versus continuous irradiation of a light-cured resin composite on shrinkage, viscosity, adhesion, and degree of polymerization. Amer. J. Dent., v.11, n.1, p.17-22, Feb. 1998.

39- KWIATKOWSKI, S.J.; GELLER, W. A preliminary consideration of the glassceramic dowel post and core. Int. J. Prosth., v.2, n.1, p.51-5, Jan. 1989.

40- LAI, J.H.; JOHNSON, A.E. Measuring polymerization shrinkage of photoactivated restorative materials by a water-filled dilatometer. Dent. Mat., v.9, n.1, p.139-43, Mar. 1993.

41- LIBMAN, W.J.; NICHOLLS, J.I. Load fatigue of teeth restored with cast posts and cores and complete crowns. Int. J. Prosth., v.8, n.2, p.155-61, Mar. 1995. 
42- LÜTHY, H. LOEFFEL, O.; SCHÄRER, P. Zirconia posts and cores: factors influencing retention. J. dent. Res., v.74, n.3, p.939, Mar. 1999. /Abstract n.228/

43- McLEAN, J.W. The alumina tube post crown. Brith. dent. J., v.123, n.2, p.87-92, July 1967.

44- MENTINK. A.G.B. et al. Porosity in resin composite core restorations: the effect of manipulative techniques. Quint. Int., v.26, n.11, p.811-5, Nov. 1995.

45- MONDELLI, J. Técnicas restauradoras para dentes com tratamento endodôntico. Rev. Dent. Rest., v.1, n.3, p.126-38, Jul. 1998.

46- MORGANO, S.M.; BRACKETT, S.E. Foundation restorations in fixed prosthodontics: current knowledge and future needs. J. prosth. Dent., v.82, n.6, p.643-57, Dec. 1999.

47- MUTOBE, Y.; KATAOKA, S. Harmony with nature: clinical application of IPSEmpress. Quint. Dent. Tech., v.23, p.7-25, 2000.

48- NOORT, R. Clinical relevance of laboratory studies on dental materials: strength determination - a personal view. J. Dent., v.22, p.04-8, Aug. 1994 supplement 1 .

49- OLIVA. R.A.; LOWE, J. Dimensional stability of composite used as a core material. J. prosth. Dent., v.56, n.5, p.554-61, Nov. 1986.

50- PICONI, C. et al. Y-TZP ceramics for artificial joint replacements. Biomaterials, v.19, n.16, p.1489-94, Aug. 1998.

51- QUALTROUGH, A.J.E.; PIDDOCK, V. Ceramics update. J. Dent., v.25, n.2, p.91-5, Mar. 1997. 
52- QUALTROUGH, A.J.E.; PIDDOCK, V. Recent advances in ceramic materials and systems for dental restorations. Dent. up., v.26, n.2, p.65-72, Mar. 1999.

53- SCHWEIGER, M. et al. Microstucture and properties of a pressed glassceramic core to a zirconia post. Quint. Dent. Tech., v. 21, p.73-9, 1998.

54- SILVEIRA, R.R. Avaliação, in vitro, da resistência de união entre amálgama e resina composta, utilizando-se quatro diferentes sistemas adesivos. Bauru, 1999. 131p. Dissertação (Mestrado) - Faculdade de odontologia de Bauru, Universidade de São Paulo.

55- SIMON, M.; MENZEL, H. Stabilization and builup of non-vital teeth using a prefabricated ZrO2 ceramic post system., Freiburg, Albert-Ludwigs University. 1996. Special reprint.

56- SJÖGREN, G. et al. Clinical examination of leucite-reinforced glass-ceramic crowns(Empress) in general practice: a retrospective study. Int. J. Prosth., v.12, n.2, p.122-8, Mar. 1999.

57-SMITH, C.T.; SCHUMAN, N.J.; WASSON, W. Biomechanical criteria for evaluating prefabricated post-and-core systems: a guide for the restorative dentist. Quint. Int., v.29, n.5, p.305-12, Mar 2000.

58- SORENSEN, J.A. et al. IPS empress crown system: three-year clinical trial results. Calif. dent. Ass. J., v.26, n.2, p.130-6, Feb. 1998.

59- SORENSEN, J.A.; ENGELMAN, M.J. Effect of post adaptation on fracture resistance of endodontically treated teeth. J. prosth. Dent., v.64, n.4, p.41924, Oct. 1990. 
60-SORENSEN, J.A.; ENGELMAN, M.J. Ferrule design and fracture resistance of endodontically treated teeth. J. prosth. Dent., v.63, n.5, p.529-36, May 1990.

61-SORENSEN, J.A.; MARTINOFF, J.T. Cllinically significant factors in dowel design. J. prosth. Dent., v.52, n.1, p.28-35, July 1984.

62- SORENSEN, J.A.; MITO, W.T. Rationale and clinical technique for esthetic restoration of endodontically treated teeth with the cosmopost and IPS empresspost system. Quit. Dent. Tech., v.21, p.81-90, 1998.

63-TJAN, A.H.L.; TAN, D.E. Microleakage at gingival margins of class $\mathrm{V}$ composite resin restorations rebonded with varions low-viscosity resin systems. Quintessence Int., v. 22, n. 7, p. 565-73, July / Sept. 1991.

64- UNTERBRINK, G.L.; MUESSNER, R. Influence of light intensity on two restorative systems. J. Dent., v.23, n.3, p.183-9, June 1995.

65- VARGAS, M.A.; COBB, S.; SCHMIT, J.L. Polimerization of composites resins: argon laser vs conventional light. Oper. Dent., v.23, n.2, p.87-93, Mar. 1998.

66- WILLIAMS, K.R.; EDMUNDSON, J.T.; REES, J.S. Finite element stress analysis of restored teeth. Dent. Mat., v.3, n.4, p.200-6, Aug. 1987.

67-YAMAN, P.; THORSTEINSSON, T.S. Effect of core materials on stress distribution of posts. J. Prosth. Dent., v.68, n.3, p.416-20, Sept. 1992.

68- YAMAUTI, M. Avaliação da infiltração marginal em restaurações de resina composta empregando-se diferentes técnicas de inserção e de ativação de polimerização do material. Bauru, 1999. 141p. Dissertação 
(Mestrado) - Faculdade de odontologia de Bauru, Universidade de São Paulo.

69-ZALKIND ,M.; HOCHMAN, N. Esthetic considerations in restoring endodontically treated teeth with posts and cores. J. prosth. Dent., v.79, n.6, p.702-5, June 1998.

70- ZALKIND ,M.; HOCHMAN, N. Direct core buildup using a preformed crown and prefabricated zirconium oxide post. J. prosth. Dent., v.80, n.6, p.730-2, Dec. 1998. 
ABSTRACT 


\section{ABSTRACT}

The purpose of the present study was to evaluate shear bond strength in three different posts and core systems. Thirty standardized cylindrical cores with $4 \mathrm{~mm}$ height and $6 \mathrm{~mm}$ diameter were prepared surrounding the posts in a special prefabricated device. They were divided in three groups. Group 1 was composed of 10 zirconia posts ( Cosmopost - Ivoclar ), which were placed in a special device. Cylinders were waxed surrounding them. The patterns were then invested and glass-ceramic ( Empress Cosmo - Ivoclar ) was heat-pressed in a EP500 furnace ( Ivoclar). Group 2 consisting of 10 zirconia posts ( Cosmopost Ivoclar ) adapted in the device and composite ( Tetric Ceram - Ivoclar ) was inserted and then light activated. Group 3 consisting of titanium posts ( Tenax - Whaledent ) was adapted in the same device as group 1 and 2. The same composite was inserted and also light activated. Specimens were tested for shear bond strength in a Kratos universal test machine. Results showed no statistical differences between groups 1 and 3 but significant difference between group 2 and the others. According to above results, it was concluded that systems used in groups 1 and 3 are the most reliable in clinical applications. 